\title{
WestVirginiaUniversity
}

THE RESEARCH REPOSITORY @ WVU

Graduate Theses, Dissertations, and Problem Reports

2017

\section{Sir Frederick Jackson: The Explorer and the Governor}

\author{
Levi Houston Sanders
}

Follow this and additional works at: https://researchrepository.wvu.edu/etd

\section{Recommended Citation}

Sanders, Levi Houston, "Sir Frederick Jackson: The Explorer and the Governor" (2017). Graduate Theses, Dissertations, and Problem Reports. 6563.

https://researchrepository.wvu.edu/etd/6563

This Thesis is protected by copyright and/or related rights. It has been brought to you by the The Research Repository @ WVU with permission from the rights-holder(s). You are free to use this Thesis in any way that is permitted by the copyright and related rights legislation that applies to your use. For other uses you must obtain permission from the rights-holder(s) directly, unless additional rights are indicated by a Creative Commons license in the record and/ or on the work itself. This Thesis has been accepted for inclusion in WVU Graduate Theses, Dissertations, and Problem Reports collection by an authorized administrator of The Research Repository @ WVU. For more information, please contact researchrepository@mail.wvu.edu. 


\title{
Sir Frederick Jackson: The Explorer and the Governor Levi Houston Sanders
}

\author{
Thesis submitted to the \\ Eberly College of Arts and Sciences \\ at \\ West Virginia University \\ In partial fulfillment of the requirements for the degree of \\ Master of Arts in \\ African History
}

\author{
Robert Maxon, Ph.D, Chair \\ Joseph Hodge, Ph.D \\ Tamba Mbayo, Ph.D \\ Department of History
}

Morgantown, West Virginia

2017

Keywords: Uganda, Kenya, Sir Frederick Jackson, Maasai, Planters, Peasants, Uganda Railway, Emin Pasha, Karl Peters

Copyright 2017 Levi Houston Sanders 


\section{Abstract \\ Sir Frederick Jackson: The Explorer and the Governor \\ Levi Houston Sanders}

This thesis is a study of Sir Frederick Jackson, an early British explorer and administrator between 1880 and 1917 focusing on three main facets of his career those being his early days as an explorer, his administration in Kenya, and then his governorship of Uganda. Within these three main focal points, various important historical topics such as the Uganda Railway, the Maasai Move, and the planter and peasant dilemma in Uganda are discussed in relation to Jackson's position at that moment of his career in order to shed some light on Jackson and the early colonial period in Africa. 


\section{Dedication}

This thesis is proudly dedicated to my grandfather Mr. James Houston Sanders, who not

only instilled in me the love of history and reading, but also the importance of knowledge and getting an education. 


\section{Table of Contents}

Chapter 1, Introduction...................................1

Chapter 2, Jackson's Early Days..........................11

Chapter 3, Kenya..........................................36

Chapter 4, Uganda, The Planters vs. Peasants Debate......54

Chapter 5, Conclusion......................................76

Appendix/Notes............................................ 83

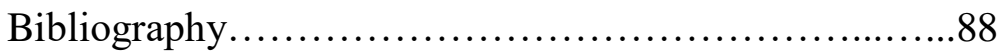




\section{Chapter 1}

\section{Introduction}

This thesis focuses on a lesser known individual named Sir Frederick Jackson. Jackson was one of the pioneers that traveled across East Africa in search of what lay beyond the fringes at the coast. Not only did this man have an exciting experience in his explorations, but he was later made lieutenant governor of Kenya and governor of Uganda for what he had accomplished in the latter half of the $19^{\text {th }}$ century (see appendix I). In the few short pages to follow I have placed Jackson into the British and Colonial African world and taken a look at three main periods of his career in East Africa. These are divided into three chapters, the first focusing on Jackson as an explorer, the second focusing on Jackson as a colonial administrator in Kenya and third being Jackson's governorship of Uganda. Each Chapter will discuss the major events that happened within Jackson's career such as the quest for Emin Pasha, the construction of the Uganda railway, the Maasai debate and the planter verses peasant argument in Uganda. Jackson was an important figure during the formation of the East Africa Protectorate and Uganda. The bulk of the formation of these two entities took place during Jackson's career and this thesis presents Jackson in the thick of these formative years as an integral part of the period.

This thesis covers the latter half of the $19^{\text {th }}$ and early part of the $20^{\text {th }}$ century from about 1880 to 1917 . This scale represents Jackson's time as both an explorer and a colonial governor of Uganda, as well as acting governor of Kenya. Jackson came to Africa as an explorer in the 1880's and helped pave the way for the creation of the protectorate governments of East Africa. He also crossed paths with some interesting men, including Karl Peters, Emin Pasha and Kabaka Mwanga 
just to name a few. This thesis will address key events in the history of the specific area of focus, namely the early explorative times, Kenya and Uganda respectively. Focus on these events will help create a broad spectrum in which to place Jackson within the context of this period. Jackson deserves to be written about because he played a significant role in the formation of the East Africa Protectorate and Uganda which adds to the history of both Britain and Africa. So in total this work is five chapters in length, one being this introduction, followed by three chapters discussing the early explorations, Kenya administration and the Uganda administration followed by a conclusion. In the finality of the matter, this thesis helps to shed some light on African exploration and the key events that were responsible for the solidification of British rule in East Africa.

Among the questions this thesis answers are: How did Jackson become an administrator and how was he involved with the creation of the protectorate governments? What was Jackson's role in the IBEA (Imperial British East Africa Company)? How did Jackson work his way up the ranks to be given the opportunity to be acting governor of Kenya? How did he finally become the governor of Uganda? These questions help to figure out why and how Jackson was a contributor toward the development of East Africa. Specifically examined is Jackson and his dealings with affairs in Uganda, especially Karl Peters the German explorer who raced Jackson to Uganda in a failed attempt to make a treaty with the Kabaka and solidify German rule in Uganda. What did Jackson do in response to the German influence in Buganda? This section focuses on the development of Jackson as a colonial administrator and diplomat bridging the gap between the early Jackson and the later and contextualizes Jackson's life.

First, the general question as to who Jackson was and what he did. This involves concentration on his early days as an explorer and illustrated his motives for exploration and why he chose to work in Africa, instead of British India or even further east. This helps to illustrate the 
type of person Jackson was in order to better understand the way he did things, such as his attitude towards Africans or his attitude towards Britain. This is also important because if one does not know what kind of man Jackson was, then it is difficult to figure out his motives for some of the things he did. Similar to what Dane Kennedy did with Sir Richard Burton in The Highly Civilized Man, this study gives examples of his character and other personal attributes to better understand the type of person he was. This thesis researches Jackson's career and attempts to understand him from a colonial perspective.

Another topic discussed is how he procured the means to do his exploring which was largely funded by himself and wealthy benefactors. Another side topic includes Jackson's thoughts about exploring and sponsoring his own travels. As one will see, Jackson came to Africa purely on holiday, he had no other intention but to hunt wild game and study birds. Obviously Jackson was a mysterious man because not much literature has been produced about him so it is therefore the purpose of this thesis to explore Jackson as an adventurer and an administrator and fit him in amongst the likes of Dr. Livingstone and H. M. Stanley.

Besides Jackson and his personal attributes and thoughts, this thesis examines the question, was Jackson an agent of empire and what was his role in the Scramble for Africa? Did he seek advancement for personal fame and wealth? The answer to this question we shall see is yes but inadvertently. Jackson was an honest man and was more concerned with hunting and having a good time rather than gaining any form of fame, which he inadvertently did when he became the governor of Uganda later in his career. This will help show Jackson as legitimate and nothing like the fame mongrel H.M. Stanley was, working to get rich and famous at the expense of a continent. When looking at Jackson, moreover, I found that he was unlike any explorer of the age. He did not follow in Livingstone's path because he wasn't concerned with converting the masses nor bringing 
Western Civilization to the continent in hopes that it would benefit the population. Again all Jackson wanted to do was have a good time. He was not concerned with anything but the animal noises coming from 50 yards beyond the tree line. After reading the first few chapters of Jackson's book I found that he was indeed different, very different than the three men mentioned above.

Clearly Jackson was an agent of empire and inadvertently, so as we shall see, with his involvement with exploring and his time in the EAP with the Maasai move. Even though Jackson defended the Maasai, they still were shuffled around the protectorate and there was nothing he could do to stop it. So Jackson was responsible for the British gaining Maasai land but he wasn't happy about it. This is a key question as it illustrates Jackson's career in the EAP and how it shaped his ideas before he went to Uganda.

Next the thesis examines how Jackson viewed Africans and Africa, whether as equals or as subordinates. This topic is important because Jackson was inspired by Africa, and it held an important place in Jackson's heart. Jackson was always in support of furthering African interests and was always quick to defend Africans as we shall see in chapter three and four. Further questions include Jackson's view of Africans and their civilization and his concern with Africa as a continent for Africans with British guidance. These two important ideas are discussed thoroughly in chapters three and four and have been posed in order to deduce why Jackson was successful as an explorer and how this helped him gain success later in life. Obviously on the surface, Jackson was a successful explorer because he was awarded with a governorship so he clearly did something right. This is the reason why I chose to discuss this sub topic because I wanted to show exactly what Jackson did right, and what blunders he made. 
One of the most important aspects of this research is Jackson's relationship to guides and African labor. As will clearly be shown, if it were not for guides and African help, Jackson, as well as every other explorer of the age, would have never lasted more than a few weeks in the unforgiving interior of Africa. This helped to illustrate Jackson's ideas towards Africans because he treated them relatively well and in turn Africans treated him well which is one of the reasons in his later career he would be sympathetic towards African problem, especially the Maasai in the EAP. This topic is particularly interesting because it illustrates the idea of Africans from a colonial perspective through the eyes of Jackson. Africans aided Jackson and they played an important role in his explorations, as well as in his career as a colonial administrator. Africans were integral to the success of Jackson's expeditions because in his early days his grasp on the local Bantu languages was weak and he was largely ignorant of the geography of the mainland. Africans were responsible for Jackson's success.

With Jackson's view and sympathy for Africans comes another question of whether or not Jackson was interested in bringing Western Civilization to the "Dark Continent," or if he was more interested in just opening it to the public for the taking. Looking through his book, I found several instances where he talked about civilizing the population and introducing Western ideas to the people, such as hats and coats, in the first chapter. So in reading that piece it can be concluded that there was some sort of humanitarian nature to Jackson's East African career and it is difficult to believe that Jackson was only in it for the money.

Another topic deals with a broader idea, that being the relationship between explorers and European settlement and whether or not this ushered in the period of settlement in east Africa. This may seem like a strange question because obviously when the interior of the continent was opened this allowed an avenue for settlement with new knowledge of what was beyond the tree line at the 
coast. Jackson indeed was responsible for bringing settlement to East Africa primarily through his work on the Uganda Railway discussed in chapter three. With the promotion of the Uganda Railway through the EAP into Uganda a series of workers' settlements arose which paved the way for European settlement and was a major factor in the formation of Nairobi, the capital of modern Kenya. Some questions included: how Jackson contributed to the idea and implementation of European settlement? Did he sign any treaties with any chiefs that would have made settlement possible? Did Jackson claim any land for Britain? Was his accomplishment a catalyst for European settlement? What was Jackson's role in the East Africa Protectorate and Uganda? This part of Jackson's story needs to be told because he was responsible for a great deal more than historians give him credit. Jackson was instrumental in the creation of an empire in East Africa and he was also instrumental in opening up the interior to European settlement.

Aside from focusing on Jackson as an early explorer this thesis focuses on some of the main events that occurred during Jackson's administrative endeavors in Kenya and Uganda. The most important events that happened in Kenya during Jackson's tenure there was the creation of the Uganda Railway and the removal of the Maasai. Some questions for discussion here include: what was the Uganda Railway and why was it important? How did Jackson factor in? What was its purpose and how did it open up the interior of the continent? How was Kenya and Uganda affected by this? What was the Maasai move and how was it important to Kenyan history? What was Jackson's stance on the Maasai issue? Why was this such a controversial topic for the colonial government? Did Jackson's views on the Maasai prompt his relocation and promotion to Uganda?

While in Uganda, what did Jackson do to promote European settlement? What were the big issues when it came to European settlement and the plantation sector? What was the background issues that ushered in the promotion of African and European farming? What was 
Jackson's view on European farming? What other figures were discussing this topic? Was Jackson alone or was he following in other's footsteps? How did the competition between European planters and African peasant production of crops shape the formation of Uganda? These topics are important to this story because they help make the framework in which Jackson can be placed. Jackson was integral to the events that happened in the EAP and the debates in Uganda. Jackson has largely been left out of the history of Africa and Britain and this thesis will illustrate a figure that has become lost in the stacks at the library. Jackson's story needs telling which is the purpose of this thesis.

\section{Sources}

It should be noted that there are very few secondary sources about Jackson in existence and most sources that are available are very slim which made this project very difficult. What was striking about the primary sources available was the absence of Jackson's private papers, such as letters or diaries. These "disappeared" after his death, presumably the result of actions by his widow. In reality there is not one book that exists that is devoted to Jackson. Any reference to Jackson is usually a terse paragraph or even a sentence or two about him being a governor. The book most heavily relied upon for the second chapter is Jackson's own autobiographical work entitled, Early Days in East Africa which is a highly detailed account of Jackson's life and travels in East Africa. The book itself is of medium size, around 400 pages, but is filled with interesting chapters about exploration, intrigue, treaty signing and backstabbing which made for some interesting reading. This is the most substantial piece of primary source material used in this thesis, a book about a man written by the man himself during the period. Other primary sources used include the annual reports for Uganda and the UK Colonial Office Records CO533 series, both 
being essential to the research because they include records from the period from Jackson as well as dispatches and other official business.

As well as the primary sources mentioned above, several secondary sources were used. Oxford has printed a good three volume history of East Africa of which volumes one and two were used. The first volume is edited by Roland Oliver and Gervase Matthew and provides very thorough histories of the creation of the spheres of influence in the British sector and German sector. Jackson is mentioned briefly especially in dealing with the Kabaka of Buganda. This edited book was useful in getting some early information on the IBEA as well as the early creation of British influence in East Africa. Kenneth Ingham's book, entitled The Making of Modern Uganda, was also a source for my information of Jackson and his involvement with Uganda. The book is an older publication but a good general history of the beginnings of Uganda. What makes this book special is that the author does a good job in laying out the key events in the creation of Uganda which helps show not only how it was formed but the reason behind its formation. Coupled with D. A. Low's Fabrication of Empire, Ingham's book laid a firm foundation on the early spheres of influence in East Africa. Uganda a Modern History by Jan Jorgensen was also another secondary source. It is a book similar to the previous two but still a wealth of information about early Uganda. It explains British intervention in the affairs of Buganda as well as the involvement of the IBEA. It also has some interesting information about the peasants vs. planter's debate which proved to be useful. Many of the sources for this portion of the thesis are general histories of East Africa that have small sections regarding Jackson or the creation of Uganda as a whole.

Vincent Harlow's, History of East Africa Volume Two, as well as Mahmood Mamdani's book Politics and Class Formation in Uganda, and G.H. Mungeam's British Rule in Kenya: $1895-$ 1912; the Establishment of Administration in the East Africa Protectorate were integral sources 
for this thesis. The first two books explain the events that culminated in the peasant's verses planter debate in Uganda while the third was instrumental in the research involving the Uganda railway in Kenya.

A few other interesting books that consulted were, W.E.F. Ward and L.W. White's East Africa a Century of Change:1870 to 1970, Abdullahi Sara's, Kenya at a Crossroads, William McGregor Ross's, Kenya from Within: A Short Political History, Dane Kennedy's, The Last Blank Spaces, Norman Leys, Kenya, James Barber's Imperial Frontier, and John Galbraith's Mackinnon and East Africa 1878-1895; a Study in the 'New Imperialism. These are good sources with small sections about Jackson.

Articles regarding Jackson's Uganda administration are, Thomas Taylor's article entitled, "The Establishment of a European Plantation Sector within the Emerging Colonial Economy of Uganda, 1902-1919", and Christopher Youé's, "Planters and Cotton Capitalists: The Dual Economy in Colonial Uganda", which are pivotal articles about the planter economy in Uganda and some of the finest on record. Taylor's article was utilized more than Youé's as it dealt with the earlier period in Uganda that led up to Jackson's governorship as opposed to the latter as it dealt primarily with Uganda after 1917. These few secondary sources coupled with the annual reports for Kenya and Uganda and various tracts from the CO533 documents were a great wealth of information for this thesis.

The above sources were satisfactory for the creation of this thesis. The intent of this project is to shed some light on not only Sir Frederick Jackson and his career but also on the events that happened within his time in East Africa. These events, such as his first explorations, the Emin Pasha expedition, The Uganda Railway, the Maasai move, and the peasants versus planters debate 
in Uganda are all key events in Jackson's life and to the history of Africa and Great Britain's involvement in African. In the following chapters we will look into the life of Jackson and place him within the colonial framework and see, not only his significance, but the significance of the events that happened during his career and illustrate the colonial period of the early $20^{\text {th }}$ century. 


\section{Chapter 2}

\section{Jackson's Early Days}

In the second half of the $19^{\text {th }}$ century the interior of Africa was largely a mystery to Great Britain. David Livingstone had opened the interior to Europeans in the 1870s and Richard Burton and John Henning Speke had discovered Lake Victoria Nyanza which was later found to be the source of the River Nile. Men such as Livingstone H.M. Stanley, Speke and Burton cast a very large shadow over the rest of the explorers of the period and often these other voices were silenced. One of these explorers that was overshadowed is Sir Frederick Jackson. Jackson played a role in the formation of the IBEA and was also influential in gaining trust and treaties from the people of the interior throughout Kenya and into Uganda. Jackson's first expedition to Africa was not until 1884, ten years after Livingstone, and he was responsible for discovering what was beyond the ten mile stretch of jungle from the shores at Mombasa. He inadvertently discovered wildlife species and also discovered many different groups of people and he also raced toward Uganda to prevent a German intrusion. Along with the heavy assistance of guides and intermediaries Jackson was one of many responsible for assisting the British in solidifying its position in East African. Jackson's role in the creation of the British protectorate is crucial because he was responsible for a great deal of its organization as well as securing Uganda for the British and being a member of the Emin Pasha Expedition. This chapter is designed to be a synopsis of Jackson's early career as well as an analysis of Jackson's personal memoir, Early Days in East Africa, and show him as both a self-made man and an agent of the British Empire. Jackson is a fascinating character and 
his stories are rich and exciting. In order to see what kind of person Jackson was the discussion begins with his first outing, the trip to Africa in 1884 .

When asked why he chose East Africa Jackson said, “I didn’t choose East Africa, rather

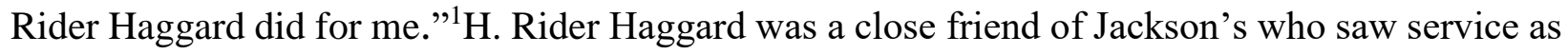
an administrator in South Africa during the 1880's and also the famous British author of the Allan Quatermain novels such as King Solomon's Mines. It was Haggard that was responsible for young Jackson's interest in Africa.

Jackson had no real interest in Africa, only in the stories that he had heard about the Zulu wars and the building tensions in South Africa. Haggard fascinated his young friend with tales of African wildlife which intrigued Jackson because he had a burning fascination with big game.

Jackson was a simple man in his early days, epitomizing the stereotypical British adventurer wearing an eye monocle and dressing well in hopes of impressing the ladies. Jackson loved his pipe and often spent his time watching birds and other wildlife in the English countryside. Jackson recounts in his book how he missed the cool Saturday afternoons looking for an elusive little yellow bird called a snipe and how dreadfully difficult it was to hit, and he was an excellent marksman. ${ }^{2}$ So ironically one of the greatest African explorers of the age never was really interested in Africa, but only the birds and other wildlife.

It was this fascination with wildlife that drove Jackson to Africa. After Haggard had asked him to go with him to Africa, Jackson gave a quick, "yes of course" and off they went to the local gunsmith to purchase their arsenal. ${ }^{3}$ Jackson had a weakness for firearms as well, having more 
than thirty in his personal collection. In his book, he gives an interesting account about Haggard and his interest in testing out Jackson's new .500 express rifle purchased from India. This is a gun large enough to fell an elephant or water buffalo. Jackson placed a target on his neighbor's cowshed and each took three shots. Needless to say the entire wall was obliterated and Jackson recalls not knowing what to do, so they left the wall in hopes that the neighbor would not notice, being that he was on holiday. ${ }^{4}$ The grapefruit size holes were eventually inhabited by some swallows and concealed for a short time. This particular story helps to illustrate Jackson and his, "young at heart" attitude, always thirsting for adventure and never having regret.

When Jackson had collected all of the supplies for his trip to Africa he was instructed to have a boat made so that he could travel up the streams that lead into the heart of the continent because that was the only real means of travel since there were no official roads, just trading paths. So he had a medium size whaling boat made to hold about fifty men so that he could have access to the inlets. Depressingly, the day before his trip Haggard backed out due to some family reasons but told Jackson that he would be to Africa days after him. ${ }^{5}$ So Jackson loaded his equipment on the ship and off he went.

On board the ship he made several acquaintances, two being the Denhardt brothers Clemens and Gustav, from Germany. Gustav could not speak English very well so he relied on his brother to do the translating. What is intriguing about this encounter is that Jackson was from Britain and the Denhardts who were from Germany and after colonies in Africa. Jackson admits to not knowing their true purpose only to discover later in life that they were destined to make a 
treaty with Sultan Ahmed bin Fumo Luti, or Simba of Witu as he was called, in order to secure land for Germany against the wishes of the Sultan of Zanzibar. ${ }^{6}$ This would lead to a German protectorate in 1886. Jackson admits that these men were jovial and cordial and that they were filled with valuable advice, but most of their ideas were nothing but, "cock and bull." 7

On Christmas day of 1884 Jackson arrived at Shela, about two miles downstream from where he was supposed to have been, and he recalls the stress of that day. He talks about how his new boat and a few of his personal belongings were accidently thrown overboard and how rude the, "dhowmen" were. He does not seem to like these people much as he says that they disgust him, but they were responsible for pitching his very expensive boat overboard and cracking the hull, which took three days to fix. ${ }^{8}$ It was in this context that Jackson also met one of his closest companions, Jim Horton. Horton was an African Christian convert who spoke English, German, Swahili, and Arabic fluently and would act as Jackson's interpreter for his first expedition. Jackson recalls the way Horton was dressed and how he was one of the most handsome Africans he had ever seen, and also talks about how white his teeth were. ${ }^{9}$ Jackson relied heavily on Horton as his attempt to learn Swahili was nothing but a farce.

After Jackson and Horton watched the porters load the small vessel they set out for Lamu, the location of the British headquarters where Haggard promised he would meet them. On his way up stream Jackson recalls a hill covered in ivory and on further inspection he noticed that it was not ivory but human remains. ${ }^{10}$ He talks about how this was a barbaric practice and that people should be given a proper burial. As will be discussed later, Jackson's misunderstanding of these practices was responsible for his skepticism. A great contributor to the distrust of local populations 
by explorers was the idea that they would discover certain Africa social norms that would be vastly different than those they were accustomed to. Clearly if one would see a pile of human remains on a river bank they would be naturally curious as to the reason they were there and probably become mildly repulsed as that is not a cultural norm in the United States nor Britain. Jackson was no different because in this instance he thought it was repulsive and negative.

Besides this small set back, Jackson felt taken back with the beauty of the interior. He recounts the coconut palms and the slight breeze and the smell of tropical flowers and the many sounds of the wildlife. He was particularly fascinated by a blundering beast that he had never seen, in this case it was a buffalo. ${ }^{11}$ Further up the river he began to see the town where his friend Haggard was located. When the party arrived a few hundred yards from the village, they came upon a mud bank and a sudden, "putrid" smell, and Jackson, jokingly, recalls it being the village latrine. He says that the smell was unbearable, even worse than Burton's description of Zanzibar. ${ }^{12}$ This soured Jackson for the entire day, or at least until he came upon Haggard's home. Jackson says that the village was a, "sink of iniquity" and that the only respectable homes were those of upper class Arab and Swahili and the whitewashed Arab fort. The most beautiful building by far was Haggard's.

By now one must notice Jackson's reliance on guides to get him safely to Haggard's quarters. This is interesting because without the interpreters Jackson would never have made it past the coastline. Intermediaries were particularly important to early explorers because they not only knew the safest routes to the interior they were responsible for essential communication between the explorer and the African population. ${ }^{13}$ 
In Dane Kennedy's book, The Last Blank Spaces, he argues that intermediaries were responsible and essential to European exploration in both Africa and Australia and that without these people explorers would not have been able to blaze the trails through an unknown continent. According to Kennedy, there were two forms of intermediaries, one being a career guide and the other local townspeople. Local people would give assistance to early explorers, like Jackson, in the form of food, water, and in some cases shelter. ${ }^{14}$ The problem with utilizing locals, as will be illustrated with Jackson's trip on his own to the town near Haggard's quarters, was that they were largely unreliable. People have routines and lives in which interruptions are not readily welcomed. Many explorers would find that local people would give them food and water, but then grow tired of their presence and find ways of ridding themselves of explorers, such as leading them off on a trail for them to get lost. ${ }^{15}$ The problem with local help was the fact that it was unreliable. Language was a barrier that delayed most explorers given the fact that there are hundreds of languages spoken in East Africa. As will be noted, Jackson couldn't speak Swahili which was one of the established lingua francas of East Africa. A lingua franca is simply a trade language used as a universal way of communication. Swahili and Arabic were two languages popular with the masses which made travel through the interior easier. ${ }^{16}$

Besides language barriers many explorers, Jackson included, had difficulties understanding local customs which fueled many explorers distrust. ${ }^{17}$ As will be illustrated later, Jackson distrusted Indians more than Africans, though Jackson disagreed with the way Indians conducted themselves. This is an example of misinterpreting local customs. Jackson primarily disapproved of Indians because he thought they were responsible for bringing ill practices to the work fields of the Uganda Railway as will be shown in chapter three. Jackson was different than most explorers though as he never had any trouble with his guides, beyond a few instances but never anything too 
serious. He despised coolies, but they were Indians and Jackson was adamant about his distrust of them.

Turning from local guides the second form Kennedy discusses is the career guide. These guides were professionals who knew the land well, could speak several languages, and typically had no familial ties. ${ }^{18}$ These professionals came from similar backgrounds of expatriation, being traumatically torn from their families at a young age and shuffled around from place to place via the slave trade. These people were hardened by this experience and were able to learn multiple languages and become acquainted with the customs of a region which is why they were so sought after. ${ }^{19}$ The difficulty with these professional guides was the fact that they were difficult to control. Kennedy says there were two main ways explorers attempted to control their guides, by capturing them, and by employing them. ${ }^{20}$

Capturing guides never worked because the distress caused by being kidnapped would lead to resistance which was dangerous to an explorer out in the wilderness of a largely unknown continent without any means of communication. Some tried capturing guides, and some bought them, such as H.M. Stanley paying \$20 for his servant boy Kalulu. ${ }^{21}$ Young boys were easier to control but were less valued than their older counterparts simply because young boys cannot do the work as adult men and would run away quicker than an older man.

Employment was the preferred way for European explorers. It created less tension and it benefited the guide because they would be paid. Jackson chose this method because it helped create a sense of trust between the guide and the employer. Many guides were successful and would reemerge time and again to help explorers on their journeys. This lead to the establishment of career guides. ${ }^{22}$ 
Many of these career guides were sold into slavery and taken to various parts of Africa or sent to India. Many guides that came from India would sign up, time and again for expeditions to prevent them from being sent back to India. So in reality these guides had to be successful in order to stay in Africa and not get shipped back to India. They needed to be guides because Africa had more to offer and they made a considerable amount of money, more so than they would in India. ${ }^{23}$

These guides were responsible for the creation of an interesting dynamic that Jackson primarily enjoyed. With reliance being placed on seasoned guides and away from locals, explorers didn't have to worry as much about food. Their professional guides could get them food and shelter from the local people which turned explorations into hunting excursions. Explorers could focus more on sport than on surviving. ${ }^{24}$ Hunting was no longer a necessity for food but now it could be done for sport. Animals could be hunted purely for ivory and bone instead of meat for sustenance. Ivory helped pay for excursions which will be illustrated later with Jackson's mission to save Emin Pasha near Lake Victoria.

Guides therefore were important to explorers because they made Africa more accessible. Without guides there wouldn't have been any explorations performed. Though guides were important to explorers, porters were equally as important. A good guide would be able to amass porters to assist in carrying packs, guns, and any other good needed for the excursion. Most of these porters, in Jackson's case, were Sidis, or ex-slaves from India and South East Asia. Their job was to simple carry anything handed to them. Many Europeans on excursions would find themselves to be one of only a few Europeans if not the only European on the trip. This would cause the explorer to hold conversations with his guide that were not business oriented, usually conversations revolving around the mundane such as weather and trip highlights. This helped forge a relationship between the master and his employee which helped shape attitudes toward guides. ${ }^{25}$ 
In Jackson's case his experience with Africa guides and local people, like the Maasai, would be carried over to his administrative position in the East Africa Protectorate and his governorship of Uganda. Jackson understood the importance of guides and it was this factor that aided Jackson in his formative years hunting big game in east Africa. What he didn't realize was that he would be forever indebted to the guides that helped him gain valuable knowledge of the land around Lake Victoria and his hunting trips were more than just fun excursions, but serious experience he would utilize years later.

Jackson's first real adventure that gained him valuable experience was upon his arrival at Haggard's headquarters. Jackson had been itching to go on a hunting excursion, but would not go for three months after his arrival in Africa. In the meantime he practiced his Swahili and also his marksmanship on the local birds. Jackson spent hours exploring the small inlet creek and became acquainted with the land. On one occasion Jackson went into the village without a guide because he had to pay them, "Baksheesh" or the fee and he was tired of wasting his money, so he went alone. While in the village, he attempted to buy a spear, shield and a knife from an Arab trader but fell short on cash so he invited the man back to Haggard's home so that he could get him the money. When they reached Haggard's home a group of seven men had amassed behind Jackson and Haggard met him at the door with ten askaris, African soldiers, with rifles. Haggard ran the traders off and gave Jackson a very strongly worded lecture about trading with local men, and that he should never invite them to his home because he could have been killed or robbed and this could have led to a British blockade which was not needed, especially with the German presence. This was the first real lesson Jackson learned in Africa. ${ }^{26}$ 
The next day Haggard took Jackson to meet the Arab consul, and Jackson says that this was a very bittersweet event because it was exciting and utterly dull at the same time. Juma lead the procession followed by two askaris with swords drawn, then it was Haggard in his red and blue uniform lined with medals and Jackson in his best hunting pants and starched collar. ${ }^{27}$ The purpose for this trip was to gain the consul's permission to hunt and that is exactly what happened. Though what is interesting about the situation is that Haggard, Jackson, and Lewali (consul) Said bin Hamid opened a few bottles of alcohol and all three were highly inebriated by the end of the meeting which ironically forged a lifelong friendship between the three men, though Jackson was never proud of his lack of will power. With this friendship came the ticket Jackson needed; he received permission to go on the hunt.

The first excursion by Jackson and Haggard was an utter disaster. Jackson was already angry because Juma was going as well as Horton and a great many porters. Jackson was interested in hunting like a gentleman and not in a pack. ${ }^{28}$ The real problem here is the fact that Jackson was used to hunting in a very different way. Hunting is a patient affair and one cannot be too eager. They must be slow and precise as wild game will startle and flee and the trophy lost. Jackson wanted to hunt his pray without the inclusion of others, but with little knowledge of his surroundings Jackson was forced to have accompaniment. As illustrated later on, these porters were loud and would generally scare away any game that would come close. Jackson wanted his independence but could not function without a guide.

Jackson grew angry with the twelve Indian servents Haggard brought along because each man carried a gun and on one occasion said that he heard a familiar click and when he looked back 
one of the coolies was attempting to climb over a branch and the bore of the rifle was pointed right at Jackson. Again another reason Jackson was angered with hunting in groups. The trigger was snagged by a rogue twig and set the hammer loose. ${ }^{29}$ Luckily the gun was not loaded or Jackson would have been wounded. It was this instance that turned Jackson away from such help for a great while, and from then on he would make sure that he was several yards away from the coolies in order to prevent himself taking a bullet to the back.

When Jackson and Haggard's party came to the camp site for the evening they rested while the coolies pitched the tents. Jackson recalls that it took twelve coolies three hours to pitch the tents because the men had no real experience in camping. Jackson grew even more angered at the coolies but never let it show because he did not want to insult Haggard. That evening Jackson settled down in his comfortable tent and did some reading and writing in his journal, which was one of Jackson's escapes. He quoted often from his journal which was a true wealth of information. He remarked that he wondered if Dr. Livingstone had done the same in his camp. ${ }^{30}$ As he drifted off to sleep the main tent pole was beginning to bow and splinter and in the middle of the night a pistol shot was heard, Jackson awoke to pitch black unable to breath. The pistol shot was the breaking of Jackson's tent pole and the tent consuming him. It took the entire camp to fish Jackson out of the mess. Jackson was highly angered and said a few choice words to the coolies that pitched his tent while Haggard laughed hysterically. So Jackson, in a fit of rage, set up his hammock on a nearby tree, but was warned by Haggard to come sleep in his tent as he would be eaten by sand flies. Jackson refused for his pride's sake and was punished brutally by hundreds of bites. ${ }^{31}$ 
Though the day before was taken straight from the pits of hades, the next day Jackson set out by himself to explore the countryside. It was here that Jackson realized that Africa was his calling and despite the insect bites, the annoying coolies, and shrewd Arab traders he loved the land. On this little excursion he was able to see many different types of birds and other strange creatures that he had never seen before. He did manage to bag a small yellow bird, He was not sure of the type, but the color was beautiful and he later had it mounted. ${ }^{32}$

On Jackson's return to camp he found that the tents had been packed and everyone was waiting for him. A runner came to announce the arrival of the HMS Kingfisher and that Haggard was needed to receive the captain, so the party packed up and went back to the village. Jackson was saddened because he only had one good day of hunting and it was this that made him want to start his own hunting party. So on his return Jackson put together a group of seventy men to accompany him on his next hunting adventure. He hired fifty porters from Zanzibar as well as Horton and a gentleman named Petis. Petis was the cook and could fix any dish as long as he had worcestershire sauce as that was the staple to every dish he made. ${ }^{33}$ He hired Mabruki who was the most senior members of Jackson's party and was also responsible for being the main guide as he had previous experience with Sir Harry Johnston at Kilimanjaro. Ramazan was in charge of the porters and keeping the guns clean and ready at all times, where Maktubu was Jackson's mail runner. Sudala was the boat and oar specialist and helped navigate the rivers and "Lift Up" was the comic relief. Jackson often was curious as to why he hired Lift Up because the only words the man could say were "left oop" he was rather worthless but Jackson was sympathetic towards him. ${ }^{34}$ He said that Lift Up liked to give orders but rarely took them. 
Jackson then began to organize two grand hunting trips, one from M'kumbi to M'konumbi for one week; then the second from M'tangani to Fungathormbo to M'pekatoni. Jackson was fully supplied by Haggard and he even accompanied him on his first hunting trip, which was cut short by another ship arriving with yet another worthy sea captain, Captain Rainer of the HMS Woodlock that forced Haggard and Jackson to return. Jackson was angry this time, but did not let Haggard sense his frustration because he was his friend after all. After they delivered the sick captain back to the coast Haggard suggested they return and pick up where they left off, so the men along with Jackson's party headed back to continue their journey. ${ }^{35}$ Jackson was dropped off at a village called M'tangani where he made acquaintances with chief Sherifu Abdurahman who resupplied Jackson because the stock was getting low at this time. Abdurahman was responsible for giving Jackson permission to hunt on his land and also was the means for Jackson getting to his hunting site, Fungathormbo. Jackson now had his heart set on the majestic hippopotamus, one because he had never seen such a beast, and two he wanted a large trophy to display at his home. Jackson was warned by Juma and Sadala that the hippo was a dangerous animal and that if startled or angered, would rip through a man without even thinking. ${ }^{36}$ Jackson was not afraid and so they made camp and went out hunting that evening.

Jackson's account of the hippo hunt is one of the most entertaining stories he told in his memoirs because he only took with him Juma and Sadala. The rest of the, "incompetents" would make too much noise, so Jackson, Juma and Sadala went to the lake. ${ }^{37}$ The sun was just beginning to dive behind the horizon and the land was getting dark, but Jackson was sure he would bag a hippo, so the men crept up behind some papyrus reeds and waited. As the world around them got 
darker and darker they could hear the groaning and splashing of the group of hippos some twenty five yards in front of them. Jackson then whispered to Juma and Sadala to make ready the firearms. So, Jackson was given an unknown weapon, as he states in his journal, and took aim at a large shadow, now 15 yards in front of him. Jackson aimed and in his haste to make the kill pulled both triggers and fired both barrels at once jolting him back into the reeds. The shot hit a target, but the shadow Jackson was aiming for did not fall and he was puzzled. Just then Jackson heard a blood curdling sound and looked up to see that shadow charging over towards him. Both Juma and Sadala screamed and took to the run and left Jackson alone in the darkness. ${ }^{38}$ Jackson would never forget this. So he waited and watched the large figure as it nudged the smaller figure and Jackson came to the realization that he had killed an infant hippo instead of the Bull hippo, it was the mother that was making the noise. Jackson says that he had never been this frightened in all his life because he knew that the mother would soon be looking for the killer. So he waited and soon she went away. On his return to camp Juma and Sadala tried to apologize, but Jackson merely shrugged them off. He was angry for them running and often held grudges, but only to those that betrayed him.

In the previous illustration, one can see Jackson in his most vulnerable state. He was new to Africa and all that comes with it, the people, customs, ways of life and the land. Jackson was under a heavy state of culture shock, but he quickly adapted. He was very interested in the game and was primarily focused on hunting. This was the driving force for Jackson, not political intrigue, or going on relief expeditions, or charting the uncharted. Jackson did not come to convert the masses like David Livingstone, nor did he come to look for a man who had been thought lost or 
dead, like Stanley. He did not make the trip to search for riches or the source of an ancient river such as Speke or Burton. Jackson came to Africa for a holiday. He had no intention of becoming famous nor discovering some long lost city of gold or deciphering an unwritten African language or spreading the Gospel. Jackson wanted to hunt and have a good time. He came with little knowledge but, within a year, would gain a great deal of it from his personal experience and his rubbing of elbows with some very influential people.

Late in 1885 Jackson moreover found himself on Zanzibar Island, several hunting excursions behind him. He was hardening well and was finally getting used to the climate. He was staying at a popular French hotel when it came to his attention that his duty was to meet with Sir John Kirk the British consul on Zanzibar who wanted to gain control of the mainland through the help of Arab infiltration. ${ }^{39}$

Jackson spent a great deal of time with Kirk and it was at a dinner engagement that Jackson was introduced to Major H. Kitchener who would go on to lead men in the battle of Omdurman and secure the Sudan. Jackson was impressed with Major Kitchener and spoke highly of him, with the exception that he borrowed a copy of King Solomon's Mines, a favorite novel. from Jackson and never returned it. ${ }^{40}$ Despite this, Jackson admired Kirk's work with the abolition of the slave trade in 1873 and would always remember his days at Zanzibar. His true gain from Zanzibar was one of his dearest friends named James Martin. Martin was Maltese and was born in 1857 and rose in the ranks of Joseph Thompson's expedition party and on his death was awarded second in command. ${ }^{41}$ Jackson was introduced to Martin at Zanzibar and he knew that Martin was brilliant, though mainly illiterate; Martin had a knack for commanding large numbers of men successfully. Jackson so loved Martin that he taught him to write his name, though only being concerned with “J. Martin." Jackson also helped Martin to become a subject of the British Empire. Jackson's last 
deed for Martin was helping him to become a Freemason. Jackson said that Martin became nervous because he knew he would have to sign the register upon his initiation, so Jackson helped him with learning to write his first name as well as the memory work involved with freemasonry. ${ }^{42}$ Jackson was proud of Martin, and he would remain one of Jackson's most treasured companions.

Jackson's early career was filled with different companions and cohorts, and by the end of 1885 into 1886 he found himself in the company of Sir Harry Johnston, later famous for being a key figure in the British scramble for African soil and of Uganda fame, at Lamu urging him to venture up the Wami river on a hunting excursion. ${ }^{43}$ Jackson recounts Johnston as being a flighty man who was very impatient and often shot too soon and missed though he was a jovial, likeable fellow. ${ }^{44}$ Johnston became weary of the heat and insects and so he made the trek back to Zanzibar for some relief, though Jackson pressed on looking for that prized trophy. It was here that Jackson would have his first encounter with the Maasai.

Jackson learned of the murder of a Reverend Houghton and his wife at Golbanti by a group of Maasai warriors and was told that it was imperative that he stay and wait for the lewali, which he did. Jackson waited for three weeks and in that time two survivors of the Houghton massacre surfaced, a cook and a young boy named Makau. ${ }^{45}$ The cook told Jackson that the Maasai had come and killed everyone in the mission violently without any remorse. Though Jackson was appalled by this he says that the Maasai who did this were a "mixed lot" and not real Maasai but of the Arusha, a group who mimicked Maasai dress and custom. ${ }^{46}$ This is a foreshadowing of Jackson's later involvement with Maasai land issues, but that is for later. Jackson was not fearful of this occurrence and proceeded to Mareneni and arrived in July 1886. Though this mission was an ultimate failure, it was Jackson's first experience with the Maasai which would greatly influence the way he viewed them later during the Maasai move. 
Jackson was now interested in the Maasai because they were elusive to him. He did not fear them, but he was cautious. So in true explorer fashion he set off on yet another adventure, this time to Taveta in the later months of 1886. In these months Jackson would begin gathering men for his party and insisted they all have firearms, for hunting purposes ${ }^{47}$ It was on this trip that Jackson came face to face with Maasai warriors.

While on the hunt across the flatlands, Jackson saw a group of thirty men one mile off masked by the tall grass and was unsure who they were. He gave the order for the company to stop and watch. The men moved forward as Jackson moved forward until both parties came face to face. Jackson sent for his interpreter who explained who they were and their purpose for being there. To Jackson's relief the Maasai shook hands with himself and his men, and tensions were alleviated. ${ }^{48}$ Jackson wanted to impress these people, so when a few elected to stay he did not turn them down. Jackson was curious about these people, how could men such as this be responsible for the ruthless killing of Christian servants?

Jackson wanted answers, so he took up the Maasai offer to visit their village. Jackson was impressed with the people as well as the organization of their village. He said that the Maasai found his boots to be most peculiar because they had nails in them and Jackson found this most interesting. ${ }^{49}$ It was this key encounter that would be a pivotal experience in Jackson's career. His relation with the Maasai was deep especially when they were forced to relocate during the Maasai move some years later when Jackson was in Kenya. Jackson was sympathetic to the Maasai in Kenya because they had shown him such hospitality during his early days. This, as will be noted was a deciding factor in Jackson's defense of the Maasai during the relocation. 
By this time Jackson was well acquainted with Africa and he had gained a great deal of experience as well as a tolerance to the land. It was now time for Jackson to take up his most intense adventure to date, using his skills and knowledge of the interior to lead an expedition of the newly formed IBEA to the south east corner of Lake Victoria to relieve H. M. Stanley from his journey to save Dr. Emin Pasha from Uganda. ${ }^{50}$

Early in 1887 Henry Morton Stanley went looking for Dr. Emin Pasha, a German doctor who had a great cache of knowledge about the kingdoms of the interior of Uganda. Dr. Emin had become stranded in Uganda due to the revolt of the Mahdi and civil wars. He was cut off. So in true explorer fashion Stanley took his gun and bottomless checkbook and crossed the Congo in search of Dr. Emin. ${ }^{51}$ This was another risk for Stanley but he wanted the publicity, and Jackson says that Stanley was ruthless enough to go after fame any way he could. Jackson did not have a great deal of respect for Stanley, but he was willing to go to his aid under the flag of the IBEA.

The IBEA received its official charter in September 1888 as a way to govern the land between Mombasa and Lake Victoria. ${ }^{52}$ Jackson, finding himself back at Zanzibar, heard many people talking about William MacKinnon forming a company to take control of the interior. It was MacKinnon who organized the Stanley relief expedition and under George MacKenzie's recommendation Jackson became second in command under Captain Swayne. ${ }^{53}$ Jackson refused to be paid at first, but after some deliberation and a good payment package, Jackson agreed to go on this adventure through Maasailand. ${ }^{54}$

Jackson traveled to Mombasa where he met with his party, Captain Swayne, Dr. A.D. Mackinnon, General Lloyd Mathews, and a man named Edmunds who had experience in West Africa. The rest of the party consisted of local Arab and Swahili people totaling $350 .{ }^{55}$ 
Jackson's party then set out for Gulu Gulu, where they added Clifford Crawford and Major Kenrick to their party and Jackson received his first real taste of Capt. Swayne. Swayne was not a good choice for the position of leader. He was not interested in relieving Stanley but only interested in hunting, much like Jackson a few years prior. Jackson remembered how foolish Swayne could be running around camp at dusk dressed in full hunting gear carrying the heaviest gun he could find, and just as the sweat would begin to pour and his breath would run out, Swayne would stop and aim at the tallest tree he could find and fire and yell, "was I steady Jackson, was I steady?"56

When the IBEA party made it to Gulu Gulu, Jackson realized that already the group was dwindling. People were deserting left and right, the water was low and the guides were very poor so Jackson made the decision to return to Mombasa and see what further orders he could get from Mackenzie. Jackson was furious with Mackenzie's lack of initiative and his gifts of money were totally worthless. Jackson had wished he would have hired Indian police instead of local people. ${ }^{57}$ Jackson disagreed with the way the help was paid three months in advance and given a new muzzle loading rifle. These men could sell the rifle and get more money on top of their advance pay and then run off with the money. This is what plagued Jackson's first attempt at the mission. ${ }^{58}$ Jackson also demanded that Martin and Gedge be summoned and brought back as help to which MacKenzie agreed. Jackson's orders were to strictly acquire ivory, sign as many treaties as possible and to meet Stanley at the south east corner of Lake Victoria and give him relief. ${ }^{59}$ The ivory would help pay for the trip because of its high demand and value. It was important to sign as many treaties as possible with local chiefs in order to help gain control of the area around Lake Victoria for British interests and to prevent the German influence.

The IBEA caravan was not well supplied, but they headed back on their mission. By the fifth night all were ill due to bad rations. Jackson wrote back to MacKenzie and he sent new guns 
and food to Teita where Jackson's troop was held up. Jackson encountered the Wateita and expressed his interest in them. He said that they were a very likeable people and gave his company shelter. ${ }^{60}$ Trekking on from Teita they crossed through the Taru-Maungu area which was a thick mess of sharp thorns and forest. The group suffered many desertions through this area and all were glad when they broke through to the Tsavo River where they were able to get some reprieve from the thicket. From Tsavo the party continued to Kibwezi which was a rather dull trip with little to no wildlife. From Kibwezi they marched on to the Andei River where they came in contact with a Maasai raiding party. They did not show any aggression, but only wanted water and rest which they were given. ${ }^{61}$ From the Andei they pressed on to Kibwezi where they spent Christmas and met with the Kamba people for the first time.

Between January fourteenth and May eighth no further supplies were received by the party and they were worried because they knew that once they arrived at Machakos that they would not be resupplied. Jackson, being concerned with the lack of communication, made the order to return back to Mombasa to resupply via the Mamesa-Ego road which was easy traveling. Jackson was either going to press on or resign. ${ }^{62}$ On the way back to Mombasa, Jackson was able to weed out several men from the party and on arrival at the coast the party was resupplied and back on the path to Machakos, though this time there would be very little rest and by July twenty-seventh Machakos was in sight of the party.

By early August Jackson's men were ready to head towards the lake. They decided to head to Kavirando and on their way they encountered a tremendous bout with ticks which Jackson described as being from head toe. ${ }^{63}$ Through the Athi Plains, Jackson's company crossed into the land populated by the Kikuyu. It was here near the forest where Jackson met Chief Kaniri and made a treaty with him and became impressed with the Kikuyu who gave the party assistance. 
Jackson's goal now was to make it to Mianzi, and he did on August twenty-third. ${ }^{64}$ Pressing on through Mianzi to Naivasha, then Naivasha to Mau, Jackson's party was drawing near to their goal on the march to Lake Victoria. ${ }^{65}$

Jackson's troop climbed the Mau escarpment and on the other side saw Lake Nakuru for the first time. This was exciting for Jackson and from here they would descend the mountain and continue on into the Nyando River valley where they would meet with the Luo people and first hear of a man named Mumia. Jackson's party pressed on to Kwa Sundu and on November seventh they met Mumia who not only gave them shelter, but presented Jackson with some important mail. ${ }^{66}$

Kabaka Mwanga of Buganda had sent Jackson a letter in June regarding a plea for aid against the Muslim influence in Buganda and promised to pay handsomely for it. Jackson knew his orders were to stay out of Uganda and concentrate on Stanley's relief, but according to locals there had not been a European in the south of Lake Victoria for years. Jackson consulted Gedge and they decided to write back to Mwanga asking for further details. ${ }^{67}$ They sent a company flag and waited thirty days for his reply which came though this reply did not offer what Jackson was seeking so the party went north to Mt. Elgon on an ivory hunt in order to make up for lost funds. ${ }^{68}$ Jackson was impressed with Africa's third highest mountain and his party camped there in December of that year. When the fuel began to get low Jackson's party turned back and returned to Mumia's where Jackson was met with a ruthless predicament, his private mail had been opened by a German explorer named Karl Peters. ${ }^{69}$

Jackson was frustrated with this situation and quickly turned his eyes to Buganda wanting to stop Peters before he struck a treaty with the powers in Buganda. On further reading his mail, a 
catholic missionary had written to Jackson on behalf of Kabaka Mwanga stating that the situation in Uganda was desperate and that they needed Jackson's assistance against the Muslim threat. ${ }^{70}$ They promised Jackson's party good payment and a treaty, affectionately signed Simon Lourdel, "First Catholic in Uganda." Jackson took this letter seriously and quickly wrote to Peters requesting him to remain in Uganda until he arrived. Peter's neglected to do this and soon after receiving Jackson's letter headed for the coast in order to avoid him. ${ }^{71}$ Jackson despised Peter's for opening his letters and accused him of deceiving Ali, his camp guard, into thinking he was part of Jackson's party which is how Peters was able to gain access to Jackson's mail.

On March 11 Jackson left Mumia's and marched to Buganda in order to thwart Peters' insurgence, signing a treaty with Chief Wakoli at Busoga on the way. Jackson arrived at Mengo, Manga's capital on April 14. When Jackson arrived the mood had changed with Lourdel and he found that the catholic missionaries were now against British involvement. Jackson blamed this on Peters' influence. ${ }^{72}$ Jackson pushed for a treaty with Mwanga, but Lourdel was starkly against this. He wanted Uganda to be a free trading society without political influence from Europe. A decision was made that Mwanga sent representatives to the coast so as to meet with British, French, and German representatives to figure out a solution that would best fit Buganda's needs and decide to whom Mwanga would swear allegiance. Jackson knew that this would lead to some upheaval, but was prepared to do what was necessary. He appointed Gedge to stay behind in Buganda as the representative of the IBEA while he made the trek back to the coast in order to take care of matters there. Jackson's party set out for the coast on May 13, the day after Lourdel died. ${ }^{73}$ With Lourdel's influence gone Jackson would now be able to help further push IBEA sovereignty in Buganda, but strangely enough, on July 1, 1890 the Germans and British struck the Anglo-German agreement 
where Germany would receive Heligoland for the whole of what became Uganda which prevented a great stalemate. ${ }^{74}$

By this time the IBEA would slowly begin to implode and would continue to deteriorate until 1895. By 1890 Captain F. D. Lugard was employed by the IBEA and was pushing for the company's control of Uganda. ${ }^{75}$ Lugard had been building forts throughout the British sphere of influence, but was given the order to stop in Kikuyuland and make haste to Uganda and establish order, this though being much easier said than done. When Lugard took charge in Uganda he found himself in a hornets nest. ${ }^{76}$ The contest between the Protestant and Catholic rivalry coupled with the Muslim influence was instrumental in creating a religiously divided Buganda. Lugard needed to somehow make peace with Mwanga in the form of a treaty, but Mwanga had fled to Bulinguge Island in fear for his life. Lugard threatened to make Mbogo, a muslim, Kabaka which quickly forced Mwanga to sign a hasty treaty with Lugard making the IBEA ruler of Buganda. Soon after, the IBEA flag was hoisted over the Kabaka's home.

Uganda was still in an uproar and Lugard had a very difficult time keeping the peace, and a lack of funds that made matters worse. ${ }^{77}$ With little capital to work with, Lugard contemplated withdrawing from Uganda and in 1891 when an attempt at funding a railway line from Mombasa to Uganda fell through, Lugard decided to reconsider matters. ${ }^{78}$

The decision was made by the British government to appoint a commissioner to assess the situation in Uganda and figure out how to deal with the upheaval there. Sir Gerald Portal was appointed to this office and arrived in Uganda in March of 1893. Portal had been an antagonist against the IBEA and decided that the only way to quell the trouble in Uganda was with British troops. By April 1893 the IBEA flag was removed, Lugard had left office, and Uganda was now 
under British control. By July 1895 the IBEA ceased to exist. ${ }^{79}$ With the passing of the IBEA, Britain gained control of Uganda. Any person who had been previously employed by the IBEA was given the option of now working for the crown which is what Jackson did. His experience with the IBEA helped him land a job as First Class Assistant in 1894, his first real government job which would give him the experience to one day return to Uganda as the governor. ${ }^{80}$

Jackson's time in Uganda was one of the most important factors in his career. As one will see in chapter four, Jackson was promoted to governor of Uganda due to his experience there. Jackson had experience in Uganda and was responsible for quelling the problems that Christians faced from the Muslim population as well as striking deals with the Kabaka of Buganda and solidifying British rule there. Without Jackson and the IBEA, Uganda could have fallen into the hands of Muslims or the Germans. Britain was able to properly gain control of Uganda through the efforts of Jackson's party and the IBEA. Jackson knew Uganda, which was one of the reasons for his promotion as shall be noted later in chapter four. Jackson's early years were the most important years of his life. Each hunting trip, each adventure helped Jackson gain the experience needed to become a colonial administrator. Jackson matured quickly in East Africa and was able to become a creditable administrator from his successes. Jackson forged a bond with the African people which he would carry with him for the rest of his career. This would be present at each key event mentioned in this thesis, the Buganda Agreement of 1900, the Maasai move, the Uganda Railway, the peasant debate in Uganda. All of these events would help shape Jackson, and he would use his skills acquired from these early formative years to deal with these situations.

When we examine Jackson's early career we see an ambitious young gentleman who was eager to jump into the action. Jackson was successful in becoming an adventurer as well as making acquaintances with other colonial personalities. What is important here is that Jackson's travels 
through Kenya and Uganda helped gain him valuable knowledge of the land and help him develop his attitudes towards Africans. His experience in these early formative years was instrumental because it gave him the tools he would need to pursue a career as a colonial administrator. It was here that Jackson would be transformed from a typical European thrill seeker, to a real colonial administrator mentality. Jackson was able to blaze through the wilds of a then, largely mysterious land and through his experience emerge with the expertise that would help him become a colonial administrator. 


\section{Chapter 3}

\section{Kenya}

During 1895-1909 Jackson had established himself in the East Africa Protectorate (EAP) and had begun his career as an administrator. In this discussion the primary focus is on the EAP and three major events that took place during Jackson's service as transport officer for the party sent to survey a route for the Uganda Railway and as deputy commissioner (later lieutenant overnor), and through his promotion as governor of Uganda. Prior to the EAP service, Jackson used his experience with the IBEA as well as contacts in Britain to gain an administrative post when British rule began in Uganda Protectorate. The construction of the Uganda railway, the flogging by Captain E.S. Grogan, and the events surrounding the scandalous Maasai move will provide three examples of Jackson's dealings with the European, African, and Indian populations and his views of each. Jackson's views of these three groups are very interesting and changed throughout his career. It is important to study these because the decisions Jackson made helped shape the EAP and Kenya.

By 1895 Britain had laid claim to East Africa and by June 15 the EAP was born. ${ }^{81}$ A loose skeletal framework was put into motion with Sir Arthur Hardinge as commissioner. Jackson then held the position as sub-commissioner of Uganda's Eastern Province due to his knowledge of the area and his experience. This loose grouping of provinces was all put under the watchful eye of the Foreign Office (FO) within the African Protectorate Department. The crux of this matter was that the newly formed protectorate took a back seat to other matters that the FO deemed more important i.e. the Nile situation and its protection. This dynamic is what created the need for tighter watch on the EAP and what better way to do this than to build a railway. 
In August 1895 the FO received a loan from the Treasury and decided to make this project a public works endeavor. Have the public build it under the administration of the FO. The plan called for a railway to be built beginning at Mombasa, at the coast, and end at Kisumu on the shore of Lake Victoria. ${ }^{82}$ The idea was to link the coast to the interior in order to promote trade, travel and for other strategic reasons such as gaining control of the interior militarily. The interior was largely a mysterious land, a place where only explorers and thrill seekers ventured. What the railway could accomplish was to create an inlet to the interior and open up the land for European endeavors. The big problem with the creation of the railway was the price. In August 1895 parliament voted for $£ 20,000$ for preliminary expenses followed by a further endowment of $£ 1,755,000$ to complete it. ${ }^{83}$ This budget was not nearly enough, and within a year the cost of the railway had grown to over $£ 3,000,000$ and by 1900 another $£ 1,930,000$ was needed. These sums angered the Treasury and they petitioned for tighter rein on the EAP and its spending.

The spending was out of control, but the real problem was timing. The FO demanded that the first 100 miles of track be constructed the first year and for the project as a whole to take no longer than four years. In reality the first 100 miles took two years to build, and it took six years to complete the 582 mile stretch of rail from Mombasa to Kisumu. On 20 December 1901 the first train arrived at Lake Victoria. ${ }^{84}$

The railway was quite a difficult task for several reasons, one being lack of proper surveys. This plagued Sir George Whitehouse, the chief engineer of the project, because he had to deal with the complaints from Britain as well as from the EAP. The land was rough because there existed so many variations, plains, mountains, lakes, rivers etc. Bridges needed to be built, or land properly excavated. Jackson, in his memoir, mentions the difficult task of building the railway when he discusses a particular trip he made to see Whitehouse. Upon strict observation of an approaching 
train, it was so wet from the rain that the train appeared to be moving like a great ship riding the waves in the ocean, the engineer attempting to go as fast as possible without jumping the rail. ${ }^{85}$ Jackson said that the FO was asking too much from Whitehouse pushing for him to get the rail to Lake Victoria. Jackson said that Whitehouse was the only competent member of his staff and the rest should be fired and Indians put in their place. Though this will be analyzed later, it does shed some light on the condition in which this project was being undertaken. ${ }^{86}$

The FO was asking for a great deal from the administration because not only were they dealing with ecological issues, they were also dealing with African opposition. Construction was met with raids, especially when the railway entered the highlands in $1899 .{ }^{87}$ Now military force was needed to protect workers from violent protests and African aggressions. These acts of violence slowed the construction and also created an interesting dynamic between the EAP workers and Africans. It seems that both parties were in a chess match, one taking the offence and the other the defense and vice versa. One attacking and killing and the other seeking retribution. The Nandi gave the most resistance to the railway and were highly militant and did their best to disrupt construction going as far as ripping down telegraph poles and confiscating the wires. ${ }^{88}$ Outraged the colonial government sent an expeditionary force into Nandi country to quell the hostilities in the summer of 1900 , but to no avail. The Nandi were still violent and defiant.

The Crown was so determined to check the Nandi that they employed Sir Harry Johnston, then a special commissioner in Uganda, to take down the Nandi, though this expedition fell through due to the arrival of Sir Clement Hill to inspect the EAP. The arrival of Hill made pressing on with the expedition difficult because Johnston's presence was needed and therefore he had to scratch the raid and return to meet with Hill. Hill wanted peace with the Nandi at any cost, but even Hill's 
orders could not subdue the Nandi who continued to raid in 1902 and 1903. They were eventually dealt with by $1905 .^{89}$

African aggression towards the railroad was not a surprise to Jackson. He knew that the railway would eventually meet with some form of opposition from the local population. Interestingly, Jackson held a great deal of sympathy for the Nandi. He knew the real reasons for their revolts and understood their grievances. With the railway jutting through the heart of the EAP, platforms and stations began popping up, Nairobi being the classic example. Around these developed small towns and in these towns anything could be found according to Jackson. ${ }^{90}$ Indians made up a great deal of the population due to their usage as workers on the railway. Jackson mentioned that Indians brought with them unorthodox practices and customs saying the Indian camps; "apart from squalor, they were crowded with prostitutes, small boys and other accessories to the bestial vices so commonly practiced by "Orientals." Jackson detested these places because he deemed them lowly places full of barbarians. ${ }^{91}$ With this statement Jackson makes his biggest case for the Nandi. The Nandi were rebelling because their way of life was threatened. Their wives and children were being drawn to the glamour of the carnal practices of the camps and therefore ruining and infringing on the Nandi way of life, and Jackson was in strong support of this effect. ${ }^{92}$ Jackson was a Nandi sympathizer because he knew their real problem. The Nandi were fighting for their social norms not necessarily for land. The larger picture here is the fact that nothing was done about these camps and small towns until the end of the construction of the railway which is the reason why the Nandi continued to raid up to 1905. This is a great example of Jackson and his support of the African. He knew that the Nandi were not hostile because of the railway. He knew they were fighting for their way of life. 
To be frank and in defense of the Indians, any project throughout history, the Pyramids, the Parthenon, the Coliseum, etc., would have been followed by practices of ill repute. Even London had places of low social standards. This was not exclusively an Indian dynamic, like Jackson alludes to though he makes a good case for the Nandi. However, Jackson during his time in the EAP, was always looking out for the best interests of Africans and this is one good illustration.

The completion of the railway not only helped open the interior to trade and transport, but also paved the way for the creation of towns as mentioned previously. Forts, camps, and small towns began to spring up along the newly completed railway which was responsible for bringing in administration. Administration was essential to the successful running and organization of the land around the railway as well as collecting taxes and revenue to make the railway pay for itself. ${ }^{93}$

The Uganda railway was important to not only link the coast to Lake Victoria but also for establishing European rule in the EAP. The railway opened up the interior for settlement, which requires settlers and the larger issue was who would protect the settlers? The railway also lead to the establishment of a public control force. Troops were needed to protect the new settlers. The main effect of the railway beside the creation of an established troop-based protection system was the fact that the railway helped facilitate European settlement. Yes, troops were needed to help protect the European population, but they were also needed so that Britain could flex her muscles without having to worry about African contention. Britain knew that opening the interior would also open up ways of other foreign powers working their way in and troops would help protect British assets in the region. Without the railway European settlement would not have been successful. 
During Jackson's time dealing with the railway, he was heavily involved as a surveyor and administrator in the transport office. Jackson was responsible for surveying the proposed land before the railway arrived to see if it was suitable for construction. Jackson describes the first 200 miles of track running though howling wilderness until it reached Nairobi and there it became more palatable. ${ }^{94}$ Jackson was all too familiar with the troubles the line faced with mud, rivers, hills and mountains and was in total support of Whitehouse as mentioned previously. Whitehouse dealt with a great deal of nagging and Jackson knew the frustration of being nagged in both ears. It was during this time that Jackson forged his opinions of certain groups of people, Africans, Europeans, and Indians respectively. Jackson claims that though the FO was building the rail it was really an Indian show. ${ }^{95}$ In his memoir there is a touch of animosity in this statement which is difficult to interpret. Was he scoffing at Indians looking down at them as slaves, or was he simply stating the facts as they were on the table? It is easily deduced that Jackson supported Africans, but thought very little of Indian workers. He says that the workers are lazy and often tried to nickel and dime the administration to death. As an illustration, Jackson recounts a time when he was on the platform at Makindu and met the Indian stationmaster and paid double for night passage to Kibwezi as well as a telegraph to the master there requesting quarters and provisions for his eighty men. When Jackson arrived at the platform at Makindu the master ignored him and acted as though he did not understand English. ${ }^{96}$ This infuriated Jackson, and after a heated exchange, he was able to get his men on the train. This irritated Jackson because he was a man of principle and no nonsense. In the rest of the chapter, he threw subtle stabs at Indian workers to the point where he blames them for the Nandi revolts. He also is irritated by Indian workers asking constantly for his papers and then holding their hands out for a tip. Jackson was appalled by this as well as the camps these men stayed in. ${ }^{97}$ 
Jackson was most displeased though with what he observed to be the Indian lack of respect for superior officers after their work was finished. One instance involved a young man who refused to acknowledge Jackson. It was not that he did not salute him, but the fact that the young man ignored him when he ran into him face to face. Jackson was a man of honor, and that was a serious blow. In these cases Jackson's relationship with the Indian population was negative. He did not care for them nor did he have much respect. He resented the fact that the camps were responsible for African uprisings and that there was little he could do to stop it. Throughout Jackson's entire time on the Uganda railway he understood the storm that was brewing. He knew that Africans were in trouble, from the Indian population as well as the European population. He knew that European settlement would disrupt thousands of people and that it would be up to him to be a voice of reason. It was this quality Jackson exhibited during the E. S. Grogan flogging incident of 1907.

The E.S. Grogan incident will be examined through the eyes of Jackson and a lengthy message to the Secretary of State for the Colonies. In the early morning of 14 March 1907 three Kikuyu men were accused of insulting some European women. The police not taking action against them lead to Captain E.S. Grogan, along with several other men in his company, severely flogging the Kikuyu men followed by a hasty trial and a rather weak prison sentence and small fine. ${ }^{98}$ When the news came to Jackson, then acting as commissioner, he was outraged and immediately began drafting his dispatch.

In this particular case, Jackson was completely in support of the poor Kikuyu men who were beaten. He begins his lengthy dispatch with a synopsis of events leading up to the flogging. By 1903 settlers from South Africa had been pressing for settlement in the highland due to the nicer climate and suitable land. It was this dynamic that the South African settlers brought with them when they moved to the EAP. Jackson says that these settlers were rather rough individuals 
and grew impatient with the slower ways of the EAP. He blames this as a cause of the flogging because the settlers from South Africa were vagabonds according to him. ${ }^{99}$ This, coupled with slow administration, led to unpleasant settlers. Settlers were doing poorly because they were growing beans and potatoes, a far cry from cotton or sugar. The settlers were starving because they could not make enough money to sustain their farms and to get a loan from a bank took a very long time. They wanted to invest in crops that took longer to cultivate but paid more, but they could not get the funds to support that type of farming. ${ }^{100}$

This notion coupled with other unrest was the grounds for the flogging. Jackson placed further blame on a local newspaper. He credited social unrest to The Star newspaper because it was full of deceit and false information. He blamed this paper for being the cause of the incident. ${ }^{101}$

After Jackson placed blame on the newspaper, he then went on to talk about the Colonist's Association and how it was formed from the Planters and Farmers Association and a few key members were writers for The Star. Early on, in the infancy of the Colonist's Association, they were primarily concerned with agriculture but later dabbled in politics. The group was filled with agitators from Nairobi, their only goal being to wreak havoc and create distress amongst the settlers. Some of these characters included Major Burn, reportedly deported from British Honduras, Captain Fichat a land agent from South Africa, and Mr. Wilson a former district clerk of Machakos. ${ }^{102}$ According to Jackson these men were, "absolutely unprincipled demagogues who care nothing for real interests of the country and have no thought beyond their own ambition and advancement." ${ }^{103}$ These men had the power to sway public opinion and were considered dangerous by Jackson. Out of these men Jackson detested no other more than E. S. Grogan. 
Grogan came to be leader of the Colonist's Association in 1907 and seemed at first to Jackson to be a rather benign figure. He seemed to be in support of agriculture and not much into political muck raking, though this was totally wrong. Jackson described him as a willing fellow that was a sly talker and moreover a conspirator who totally betrayed his confidence since he was working for unscrupulous goals. ${ }^{104}$ Jackson's big problem with Grogan was that he supported the idea of settlers, primarily the South African settlers, denying Africans their land and cattle, Jackson said that if it was to be a protectorate then it was up to Britain to protect the people and not infringe on them. ${ }^{105}$ It was up to the protectorate's administration to act and serve.

Jackson argued that the government had already put Africans in reserves, moved the Maasai to make way for European settlement, pushed Africans to work for Europeans, bent over backwards for European settlement, and it was these acts that were turning Africans into slaves. Jackson was well aware that the deck was being stacked in the favor of Europeans and he wanted a fair deal for Africans. He knew that, soon, covetous eyes would be turned to the fertile land that African herds had grazed on for years, and that one European sympathizer would be all that was needed to promote settlers' needs. Men like Grogan saw land they wanted and went to get it by force, and Jackson was well aware of this.

Jackson blamed Grogan and his acts on the Wehner trial which convicted a European of killing an African but then the sentence was repealed by the Privy Council for lack of organization. This was very significant because it was a case where a European was let off for simply being a European ${ }^{106}$ Jackson blamed Grogan's sentence in this trial because with the previous man being released, this made Europeans seem to be above the law. Any sympathetic judge would be lenient on a European when it came to hostilities towards Africans which is what happened in Grogan's case. He was put in jail for a month and forced to pay a small fine. Jackson told the powers that be 
that this was not punishment because European prisons were too lenient and were not really good forms of punishment. He argued that letting Grogan off easy was a detriment to peace in the EAP because Europeans would continue to become more hostile towards Africans, especially the South African settlers. ${ }^{107}$

With this dispatch Jackson presented himself as a supporter of African development and rights. The lengthy dispatch also shows how Jackson cared about the situation and that he collected all the facts regarding the setting for the flogging. Jackson did not care much for South African settlers nor did he like those men who pushed their weight around like Grogan. Jackson wanted Africans to receive equal opportunities as Europeans, but knew that this would never happen as he alluded to in his, "bending over backwards" portion of his dispatch. He recognized all the problems that came with the African question and knew that the answer would not be an easy one because of the crookedness of a certain few.

Five years prior to the Grogan case in 1902, a large portion of the south of the EAP was occupied only by a few sparse Maasai in the highlands on Uasin Gishu and Laikipia and by 1903 the Colonial Office (CO) as well as the settlers were beginning to realize how wonderful the land the Maasai inhabited was for farming and also how few in number they were, far less than the Kikuyu and probably easier to manage. This is what sparked the idea of moving the Maasai.

What attracted settlers the most to the land of the Maasai was the fact that the Maasai were on it. The ground must be good if other people have chosen to make it their home. It must be perfect for farming because of all of the cattle that grazed the land. This was the thinking of the settlers. The Rift Valley was also an attractive place because the railroad was positioned right in the middle of the land which would make it easier for farmers to get the material goods they needed 
in order to function. Cattle and the railroad made the deal better for the European settlers, and this idea of gaining, "sweet" land came with a price. ${ }^{108}$ The FO became aware the many new settlers were applying for land located within the Maasai grounds. Sorrenson says in his book, Origins of European Settlement in Kenya that a Major Burnham applied for a 500 acre land grant at Naivasha right in the middle of the Maasai land that was inhabited by some 3,000 Maasai, 150,000 cattle and over 250,000 sheep. By 1903 other people were beginning to settle on the land as well and this posed a great threat to the Maasai and the FO would soon notice. ${ }^{109}$

It was not hard to notice that settlers were trying to get the Maasai's land. As the Naivasha administration official Bagge pointed out, the Maasai had been in that area for over 100 years and that the land was rightfully theirs. Jackson agreed with the official and wrote in his memoir that European settlers could stake out huge areas embracing all the very best grazing grounds on both sides and for the greater part of the length of four out of the only five rivers that run into the lakes Naivasha, Elmenteita, and Nakuru regardless of the established claims, "for I maintain they are established claims of the Maasai." ${ }^{110}$ Jackson could see the storm coming and he knew that once settlers were introduced to this land that they would want more of it. This was an interesting case for Jackson because this statement shows that Jackson was in support of the Maasai. He admits that this land had already been established as Maasai land and should not be tampered with. Jackson implied that the European settler's quest for land would eventually lead to running the African population out. He said that the settlers would stake only the very best ground near the important rivers so that they could establish successful farms while Africans, in this case the Maasai, would be left to live on whatever land was left an example of social Darwinism. Within this torrential period, Jackson showed his true opinion in this matter. He knew who the Maasai were because he had experience with them back in his early days in Africa. He knew that they 
were cattle herders and understood their ways of life. Jackson had a deep respect for the Maasai and he knew that they would turn hostile if not fairly dealt with and given a fair deal. In this instance, Jackson was in support of a fair deal. He knew what settlers were capable of doing and what would happen if the Maasai were forced to move from their fertile ground to other places less attractive. It was not fair by any stretch of the imagination for the Maasai to be forced to give up land that had long been under their control. Jackson's statement to Bagge is important because he recognized the peculiarities of European settlement and what it would eventually do to the EAP. Jackson knew this all too well because of his close relations with the Maasai.

By 1904 officials were seeing what would soon blossom into a huge problem for the FO. How the issue of the Maasai would be dealt with was a mystery at this time, but some ideas were beginning to surface. Many suggested looking to the United States as a model because they had begun the process of implementing a reserve system for Native Americans which seemed to be successful, so the FO decided to look into the idea of grouping the Maasai into reserves that would keep them together leaving room for the settler population. With this idea in mind, the task was given to $\mathrm{C}$. W. Hobley, a provincial commissioner, to survey the proposed land to see if conditions were proper for the reserve and just how much land was going to be dealt with. ${ }^{111}$ By February 1904 Hobley had found that there were more petitions for European land than there was available ground and he concluded that a modus vivendi would have to be reached in order to prevent a complex situation which would involve driving out a group of people from their homes, and have a negative impact on the FO. He also made the claim that it was unjust to drive the Maasai out, especially since they had trusted the British system and officers. Hobley also predicted that the coming of the settlers would simply be the lull before the storm because they would at first use the Maasai cattle for their own purposes, but once they grew strong enough and gained their own herd 
would eventually try to push the Maasai out. Hobley prophesized that the settlers would either push out or blot out the Maasai for their own means, and the only way to prevent this was to reach an agreement that organized the land in such a manner that ample land and water sources were given to the Maasai and the settlers which is what led to the creation of the Maasai reserves in the Rift Valley. ${ }^{112}$

However the Maasai reserves were not attractive to every administrator in East Africa, especially to Sir Charles Eliot. Eliot was the commissioner of the protectorate from 1900 to 1904 and according to his philosophy the Maasai reserves were nothing but a waste of time. He believed that the settlers should be given free reigns to settle where they wished and that the Maasai should be left to interpenetrate the settler farms in order to initiate a process of civilizing. The Maasai could work for the farmers and gain valuable skills. Eliot accused Jackson and Bagge of being overly sympathetic to the Maasai and confusing the Maasai's right to land with their right to monopolize certain districts. ${ }^{113}$ This idea would lead to a rift between Jackson and Eliot. Jackson and Eliot battled back and forth about the idea of moving the Maasai, and in 1904 Jackson submitted a complaint to the FO about Eliot and his neglecting of the Maasai case as well as having a private discussion with high ranking officers about Eliot's conduct. Eliot grew angry at this and threatened to resign as commissioner. Ironically Eliot's tantrum backfired on him and the British government released him as the commissioner of the East Africa Protectorate. This is a prime example of Jackson in opposition to European powers. He was so disgusted with Eliot that he wrote his famous letter which eventually led to Eliot's dismissal which worked in Jackson's favor as he did not like him anyway. This was a win for Jackson because Eliot was not very impressive at his post and was a perpetual complainer which led to his departure. 
Eliot was replaced as commissioner by a gentleman by the name of Sir Donald Stewart, and it was Stewart who would get the ball rolling for the first of the Maasai treaties. ${ }^{114}$ By the end of 1904 Jackson and Hobley had changed their opinions and were in support of the move, or at least the creation of a reservation system. Jackson was interested in what was best for Africans. He said he changed his mind because he knew that if he did not support some form of reservation system that the Maasai would be hindered by European farmers taking their land. ${ }^{115}$ It pained Jackson to have to change his opinion, but it was for the best as he saw it. He said that he was glad that he was never involved with the physical move nor the negotiations because matters would have been drastically different if that were so. He also would have interpreted Olegilisu's statement, "If you wish us to go we will go, but we don't want to" instead of, "quite willing" as Sir Percy Girouard did ${ }^{116}$

Though Jackson would have been fair to the Maasai and given them their land, Stewart's plan rationalized the idea that it was easier to move the smaller Maasai population than the larger settler population. Most of the land was occupied by new settlers and he thought that, if given proper support and provisions, the Maasai would be more apt to relocate than the settlers. Stewart knew that the Rift Valley was a strategic point for the settlers being connected to the railroad and being good ground for farming. Stewart used this idea and the ultimate idea that it would be ludicrous to think that the FO would put African interests over settler interests, and he knew this all too well. He knew that there was not a single official that would undermine British settlement for the Maasai even if it was the honorable thing to do, so Stewart had to act quickly in order to prevent turmoil. ${ }^{117}$ There was one large factor that played a role in this event that weighed heavy on the outcome and that is the fact that if some sort of treaty, or agreement would not have been reached then many people would have been displaced in a negative manner, because by this time 
the assumption was that the only means of economic growth and development was European settlement. Thus this would lead to the overlooking of any humanitarian sentiments. So in order for the land to prosper, settlement had to be pressed for regardless of the cost, or at least that was the thought of the officials at the time.

With Stewart taking office in August of 1904, and the FO still in control, this brought a great deal of change to the system because, as stated previously, Stewart was in favor of a reservation system for the Maasai and heavily relied on Hobley's survey that took place a month previous. Hobley and John Ainsworth had surveyed the Laikipia plateau and they had both come to the conclusion that it was suitable for a Maasai reserve and a proposal was given to the Maasai in the Rift Valley and at Ngong, as well as Naivasha. ${ }^{118}$ According to both men the proposal was accepted by the Maasai and Olonana himself, who was considered the paramount chief by the British, agreed to it without any bribe or concession. How much of this is true is uncertain though, because, as will be pointed out later on, it is unusual for an entire group of people to totally agree with anything. It is human nature. It does not matter what is proposed, whether it be an idea that would totally revolutionize a group, they will always argue back to get some sort of compromise, similar to a man trying to get a deal on a new vehicle. Whatever price the salesman gives, the customer will always offer less, and it is this factor that leads one to believe that there must have been a factor, or multiple factors, that influenced the Maasai to this agreement. Hobley and Ainsworth were able to secure the blessing of the Maasai, and now only awaited an official's signature.

That particular signature would come with haste and the Maasai would be bound by a document that was supposedly going to help protect them. Stewart said that the Maasai seemed to be more than happy about the treaty because it contained most of their ideas, and that they only 
requested 6 months to get adjusted and moved. ${ }^{119}$ The Maasai signed the treaty saying that it was in the Maasai, "best interest to remove our own people, flocks and herds into definite reservations, away from the railway line and away from any land that may be thrown open to European settlement" and that the officers, "taking up this question are considering our best interests" and finally saying that the Maasai were "fully satisfied that the proposals for our removal to definite and final reserves are for the undoubted good of our race" the treaty was to be enduring for as long as the Maasai existed. ${ }^{120}$ The important fact of the treaty was that it contained the phrase, "enduring for as long as the Maasai exist." Stewart knew that he had to include this phrase because once the Maasai were settled in Laikipia and their cattle made the ground manageable and sweet, the settlers would then turn their, "hungry eyes" on the Maasai land. He wanted to make sure that this reserve was absolute and that no grants would be permitted.

By October 21 the treaty had been approved by the FO and an expenditure of $£ 1150$ was awarded as compensation for the move, this being given to chiefs in the form of gifts and to poorer Maasai to help them get back on their feet. This was accepted well in the FO because it was agreed that the Maasai deserved some form of compensation due to their acceptance of the treaty. ${ }^{121}$

The first Maasai treaty of 1904 looked better on paper than it did in reality in Jackson's view. The treaty was only upheld partially. Two reserves were created, one 4,770 square mile reserve to the north of the railroad at Laikipia and another 4,350 square mile reserve to the south at Ngong. This treaty also promised for a right of way between the two reserves in order for communications to be carried out between the two reserves. Stewart's plan was now partially in full swing, but he would never live to see his plan totally blossom as the poor fellow met his death a year later in 1905. That year Sir James Sadler took over as commissioner of the EAP and would further wrestle with the Maasai question because by the time he came to office there were several 
flaws that had surfaced with the treaty. The road connecting the two reserves was never set aside, which was brought to the table by the Surveying Department in 1907. By August 1908 the moving of stock between the two reserves was prohibited. The original treaty had set aside five square miles of land to be exclusively used for the Maasai circumcision practices, but this was quickly engulfed by settlers. The Taylor brothers petitioned for the land in 1908 and were awarded it the same year. By January 1909 Sadler had come to terms with the settlers and decided to meet with Olonana and the Maasai to see if another agreement could be met in order to keep both parties satisfied. ${ }^{122}$ Sadler presented Olonana with another proposed move and Olonana seemed to be in compliance. Sadler said that he would only support another move, if the Maasai were in total support as well. Soon after, Sadler sent Bagge west to see if land west of Laikipia was suitable for the Maasai to move there. The problem with the land west of Laikipia was that it was inhabited by the Loita and Siria Maasai. Bagge failed to notice this and reported that the land to the West was inhabitable, but the water conditions would have to greatly be improved. The Commissioner of Public Works was sent to check out the water crisis. As the commissioner, G. K. Watts, came to the conclusion that the area would be suitable for the Maasai to move, but it would take $£ 5,280$ to provide good water for the Maasai. Another $£ 3,000$ were added and the plan was set for approval. ${ }^{123}$

By 1910 the plan was written and a new governor had replaced Sadler, Sir Percy Girouard. Girouard was a very cunning and sly individual and was responsible for the Second Maasai move, though Girouard was not as precise as Stewart had been because he created more turmoil than actual good when it came to the second of the Maasai treaties. By this time Jackson had been promoted to Governor of Uganda and moved accordingly and relinquished his duty towards the Maasai and their land. 
The three cases above are prime examples of Sir Frederick Jackson and his views towards African and European settlers. As it is concluded Jackson was in favor of African rights when it came to land and cattle. His experience with tribes in his early years in East Africa helped to shape his points of view. He knew that ultimately Europeans would devour African land and that it was an unquenchable fire that was spreading. His detest for Indian workers and South African settlers, shows us that he was a man of honor and believed in the greater good and had little time for insubordination and egotistical people. Jackson's tenure in the East Africa Protectorate helped him gain a great deal of knowledge about how the colonial system operated, as well as valuable experience when dealing with settlers. Therefore Jackson was a man of the people and worked for the best interests of them regardless what his European counterparts thought and it was he who became the voice of Africans. 


\section{Chapter 4}

\section{Uganda, the Peasants vs. Planters Debate}

Sir Frederick Jackson left Kenya in the middle of the Maasai debate to take the office of the Governor of Uganda in 1911 and was there until 1917 with his retirement from public office. Within that short window of time, a great debate emerged in Uganda regarding its economy and the planting sector. In the typical British fashion, the crown sought to create colonies that would pay for themselves with cash crop production which was no exception in the case of Uganda. This chapter will primarily focus on three topics, one being the attitudes of the British administrators when it came to peasant and planter production, the African perspective and how the Colonial government was able to transform Uganda from a loose confederation of states to a colony filled with cotton plantations, all within the confines of Jackson's governorship. It will also serve as a guide to how Uganda evolved from the early days of the Buganda Agreement of 1900, to the period between 1917 and 1919 when the cotton industry was solidified in Uganda. Governor Jackson's colonial reports will be examined in order to shed light on some agricultural, political, and land issues that plagued Uganda and will be used to examine British influence and ethos towards the great rift that would become the planter's verses peasants debate.

When Jackson was still in Kenya, he was in the thick of a heated debate about the Maasai. As stated in the previous chapter Jackson was not in favor of European settlement, but of the rights of the Maasai which annoyed Sir Percy Girouard. With Jackson as lieutenant governor and the colonial state entertaining the idea of eliminating Jackson's office this gave them the perfect opportunity to relocate Jackson and remove him from the Maasai situation completely. The Lieutenant governor position would be eliminated and replaced by an appointed colonial secretary. 
With Jackson's exemplary service in the past he was promoted to the Governor of Uganda in 1911. It was suggested by Girouard that Jackson would be best suited for a "purely native" country due to his sympathy to African rights and thus Jackson inherited Uganda in 1911, and thrust him into another heated debate over who would control land and farming in Uganda. ${ }^{124} \mathrm{He}$ was well aware that the views of Europeans and Africans were at odds as he had prior experience of this when he was the Lieutenant Governor of Kenya when he debated over the Maasai and the multiple British attempts to relocate them as discussed in the previous chapter. ${ }^{125}$ Jackson was sympathetic to the rights of Africans and he was hesitant to side with either the Colonial Administration or the African workers. What we see in this debate is an intensely complicated matter. On one hand Jackson and his fellow administrators had European and Indian planters breathing down their necks for land. These planters wanted good, fertile land to plant their cash crops and make it rich or the mailo, or African farmland, belonging to Africans primarily in the kingdom of Buganda where the soil was at its most optimum level for planting. ${ }^{126}$

The topic of planters verses peasants is very important to the history of Uganda, not only because it shows the typical assertion of the British Empire over foreign lands, but it gives historians a look into the big issues that plagued Uganda and its administration when it came to land policies and land alienation. It is important to note that the transformation of Uganda from a loose federation of states to a working colony did not happen overnight, nor over the course of a few weeks. In fact, it evolved at the pace of a snail until the land boom of 1911 when Jackson took his position as Governor. Between 1900 and 1911, Uganda faced a series of problems that began with the famous Buganda Agreement of 1900.

In order for us to understand the problems of 1911 to 1917 during Jackson's governorship of Uganda, we must first examine how Uganda evolved into a planter society. Very little work has 
been done on this topic and there are tremendous gaps in the historical record regarding this period of Uganda's history. ${ }^{127}$ This chapter will attempt to fill some of these gaps beginning with a discussion of Uganda's evolution, starting with the agreement of 1900 which would be interpreted several times over, the agreement would be a fulcrum that would always seem to tip to the side of European planters under the guise of the humanitarian efforts employed to protect the rights of Africans.

As stated above, Uganda was slow to evolve into a planter's society, and really this was not in the full throes of operation until 1919 after the Great War. Up to 1919 Uganda grappled with the idea of land alienation, or taking land from a resident and giving it, or selling it, to a foreign settler. Local administrators were never totally neutral when it came to smaller farms and larger plantations. Obviously bigger plantations made more money which would make them more attractive for revenue creation. By 1919 these two sectors were at odds with each other when it came to labor usage and utilization of land. ${ }^{128}$ It was this year that the plantation sector took off and cotton became paramount over rubber and coffee. The plantation sector was slow to develop because of local African small-hold farms and their similar fashion of farming. If the land was already being farmed a certain way, then why would it be necessary for a foreign power to assert itself in the farming sector if there were already people doing the job. ${ }^{129}$ This was but one dynamic that impeded the growth of British plantations up to 1919.

Another reason for the impedance of European plantations, was the fact that there was a preoccupation with the harvesting of rubber from forests and rubber production. Rubber was an important item and a popular item on the world market due to its many uses. This coupled with existing African farms made for a stagnant climb for the plantation sector. The British recognized the importance of Uganda and its soil and would soon, by 1912, with Jackson as Governor, 
facilitate an explosion of production which saw the creation of farms and the exportation of coffee, rubber, cocoa, flax, sugar and tea. ${ }^{130}$

The boom of cash crop production paralleled the creation of European farms, from 19 in 1911 to 157 in 1915 and created a severe competitiveness between the African and European agricultural systems with the acquisition of land and skilled labor. This tension did not fully erupt until 1919, but the seeds of contention were planted well before hand between 1911 and $1918 .{ }^{131}$

The major source of discontent was the mishandling and misuse of land and labor by the colonial government, which centered on European plantations based on the dependence of the alienation of large expanses of agricultural land and the utilization of unskilled African labor. As European farms began to grow, planters became aggressive towards the cotton industry and its domination by Africans. This industry was centered on the production of cotton by several hundred small-holder African farms which produced cash crops and vital food crops to supplement their gains from the cotton planting. ${ }^{132}$ This hindered Afican land alienation and also provided a more attractive means of employment for workers as opposed to large scale plantations.

This factor was a major road block for the European plantation sector because if they were going to create successful plantations and grow crops that would make them and the colonial state money, they needed to deal with the question of African land. They needed to figure out how they were going to get the land from the Africans in order to create European plantations, which brings us to the Buganda Agreement of 1900 which was the treaty used to interpret African rights to land.

The Buganda Agreement of 1900 was an important document signed by Katikiro Apollo Kagwa on behalf of Kabaka Daudi Chwa and Sir Harry Johnston on behalf of the British. Jackson was also involved with this agreement as we shall see later. In the confines of this document it 
defined mailo (African) estates and also put into power the Bakungu, client chiefs led by Kagwa. The Lukiiko, the assembly of chiefs, would rule small sectors and be responsible for taxes and local legislation. The British did not employ many European administrators but instead relied on the local chiefs to administrate business as they believed they were a better choice to govern the people, not only because they were local, but because they were also friendly with the British and were Christians. ${ }^{133}$ It also defined the boundaries of Buganda and would be the basis for the later interpretation on what land would be suitable for European farms.

This agreement was key to the future of Uganda and by 1902 it would help usher in the time of European settlement. By 1902 Uganda was in its infancy and was in the transition period from being a loose set of military conquests to that of settled administration with colonial rule being solidified but only holding reign over the people of the Baganda, Basoga, Batoro, and the Bankore. This year saw the instalment of Colonel James Sadler as commissioner of Uganda, who found himself responsible for a land that had no means of production nor revenue. Sadler knew this was a big issue and it would be up to him to figure out how to please the population, both European and African. ${ }^{134}$ By what means would Uganda be able to provide for itself and be a contributing entity of the British empire? Farming would be the only viable means by which Uganda would be able to contribute any substantial revenue for the British and this brought up the key question of land allocation and alienation. Who would get land and for what purposes? Any economic scheme would have to revolve around export farming and any policy was inherently dependent on the success and application of the Buganda agreement.

This agreement formalized the relationship between colonial institutions and those of Buganda and this prototype was later extended to Nkore and Toro respectively. These treaties outlined the rights and responsibilities of Africans, taxation, local government and the demarcation 
of African (mailo) and British land. The Buganda Agreement was also an integral part of keeping peace and allegiance between the political, social and religious elites in Buganda to promote order and stability and cooperation with the British administration. The agreement allowed for the distribution of mailo estates and out of 19,600 square miles of property, 1,061 Baganda received 8,934 square miles of land for personal usage or attached in permanence to their official positions. Another 92 miles were allocated to the Uganda missionary societies to be, "held in trust for native churches." ${ }^{135}$ Besides these allocations over 10,700 square miles were designated as Crown land, and with this concession Britain owned 3/5 of Baganda land and nearly all the other provinces combined. This was the leading factor that promulgated the problem of large scale land alienation and made possible the growth of the European farm sector. ${ }^{136}$ If Britain owned a great deal of the land available, then of course they would be able to promote European farming and cash crop production. Commissioner Sadler was quick to address this problem and was largely on the side of Africans and was advised by the FO to pursue the topic carefully and that, "the matter of first importance is the raise revenue without pressing hardly on the natives or hampering European commerce." ${ }^{137}$ Sadler and the colonial government were pressured to keep the African population appeased and cooperative. This would be imperative to keeping the balance of power in Uganda and prevent any form of grievances with Africans or worse.

At this volatile stage, an influx of British or Indian settlers could upset the balance of power casting Uganda into a sea of hardship not benefiting the Colonial state whatsoever. Sadler was ordered by the FO to limit the settlement only to the Buganda province in an attempt to quell contention between Africans and Europeans. It was said by the FO that it was, "not desirable to push too quickly amongst tribes in outlying districts who have not yet become accustomed to the sojourn of white men in their midst." 138 The FO believed that by restricting European land 
acquisition to Buganda exclusively, this would help prevent any form of African concerns or grievances. As long as the surrounding territories were not being infringed upon, business would be as usual. This seems very peculiar because, as we shall see, this did not work but only added to the turmoil that would ensue in regards to alienation and acquirement of African land. ${ }^{139}$

The biggest focus of tension was not between the Kabaka and the chiefs, but the middle headmen and the peasant farmers. As per the Buganda Agreement, the upper officials of the Buganda ruling class were understood to be accepting of the agreement, but the irregularity of gains for the headmen and the taxes of the peasant led to tension. These taxes were imposed as a substatution and not in addition to the taxes collected in previous years. It was this factor that fueled peasant discontent. ${ }^{140}$

This volatile atmosphere caused the colonial government to reinforce its hold on Uganda in fear of a peasant uprising. It really is eccentric to think that the British thought by taxing Africans in such a fashion and alienating land, that the common people would be completely compliant with the situation. Luckily, there was no rebellion and the British did not need to utilize military force to keep the peace. The Colonial state recognized the level of intensity between the administration and the peasants which was reflected in the 1903 Land Ordinance an identical document to other treaties throughout the empire with the exception that Ugandans were given great amounts of land security, more so than most British subjects. ${ }^{141}$ This ordinance was only to appease the peasants and head men and to keep them from feeling left out as opposed to their aristocratic counterparts who were being taken care of, at least within the context of the Buganda Agreement.

In the agreement a clause was written in order to protect the land rights of small African farmers who resided on crown land and to help keep their property from being taken by European 
planters. One statement found in this ordinance said that "regards shall be given to the rights and requirements of the natives and in particular the Commissioner shall not sell or lease any land in the actual occupation of the natives." ${ }^{142}$ Holders of these grants were not permitted to enter villages without the consent of the headman, nor where they allowed to interfere with local rights of cutting and collecting firewood, timber, water or any other goods found within the lease hold. This coupled with the lack of structural development and respect regarding the rights of African to land, played a major role in the dissuasion of European settlement. ${ }^{143}$

These factors are what contributed to the slow process of European settlement which was so slow that in 1904 only 16 Europeans applied for land amounting to 1,000 acres. Out of that 16, only 11 were approved and further only a single grantee claimed his property. It was then that the FO, later the CO after 1905, would begin to encourage European settlement and the creation of plantations, though this would develop at a snail's pace until 1911. Even by 1911 there were only around 19 European estates mostly ran by former government officials, traders and missionaries who retired to become capitalist farmers. ${ }^{144}$ These estate owners were large concessionaries that capitalized on forest and marshland, which was particularly attractive for the Colonial government because these estates kept them from having to employ a large number of workers to do government tasks such as surveying. The Colonial Goverment left the land surveying to the concessionaries. It also made it easier to alienate land to non-Africans through the issuing of permits and licenses, and this exempted all forests and marshes from being distributed on mailo estates. $^{145}$ It was this factor that made the process of land acquisition from Africans easier, as we can see in 1905, when applications for timber and rubber were at a peak.

Some companies that applied for this land were well established businesses with already wealthy owners, who were looking for foreign locations for their business. Some examples found 
in Thomas Taylor's article were R. G. Coke who owned the Anglo-Mexican Trust Company and had $£ 2$ million of capital, Symington \& Co. worth $£ 500,000$ in African capital and another $£ 150,000$ in Ugandan enterprises, and the British Trading Co. which had the smallest amount of capital at $£ 20,000$, but had the wealthiest and largest holder of African land as CEO, Lord Cranworth. The board of directors included the Duke of Westminster, H.C.B Underwood, M. O. Fitzgerald and the Viscount Cobdam who held land in Uganda. ${ }^{146}$ All these men where wealthy landholders who had considerable influence. Most of the permits given to companies like these were for timber and rubber harvesting, as well as the exploration for minerals. ${ }^{147}$

Another example Taylor uses in his article, is that of Uganda Company Limited and its initial attempt at cotton farming with its introduction of cotton facilities. In 1904 two years after its founding, Kristen E. Borup, then manager of the company, applied for a land concession in Buganda and was interested in growing cotton primarily with coffee, tea, rubber, rice and wheat as supplemental goods. According to the Land Ordinance of 1903 no more than 1,000 acres could be applied for and any more than that would have to be taken for approval by the Secretary of State. This application was sent to the $\mathrm{CO}$ and delivered to secretary of state Alfred Lyttleton who approved the excess though some of this land was located on mailo estates. According to the ordinance, this could not happen though the Kabaka of Buganda and his regents, the Katikiro, and leading Baganda chiefs, had no problem with this as they had stock in the company. It was the Lukiiko who had a problem with the selling of mailo land. This mailo was near Mengo and the Lukiiko had it leased, but were hesitant to sell off the Kabaka's land as he was still a young child. ${ }^{148}$ The Lukiiko were adamant about keeping the land for the Kabaka, and would only agree to lease the land to Borup as they feared it would create a rift. 
The fear of a rift caused secretary Lyttleton in 1905 to reconsider his decision and he therefore retracted his approval for fear of trouble. This denied the Uganda Company the land they were applying for though crown land was offered as an alternative to the land in Buganda. The issue wasn't with the alienation of mailo. There needed to be clearer regulations on the acquisition of land and no special treatment given to Europeans in regards to African land. The problem with the Uganda Company raised an important question and challenge to the colonial government and they couldn't answer it nor did anyone want to talk about the idea of African land and who had the right to it.

This question would remain a hot debate item for the British, and by 1905 Sadler and the $\mathrm{CO}$ created a crude land policy that attempted to quell these problems, but his administration still fell short in dealing with the problem of land distribution and acquirement completely. ${ }^{149}$ Sadler knew that these problems would lead to bigger issues, but the slow process of land distribution was crippling the administration and not promoting economic growth by any stretch of the word. By 1905 Sadler had left office and his successor was Sir Hesketh Bell. He was passed the torch and tasked with solving the land issue Sadler was hesitant to mend. Bell would be governor of Uganda until 1910 and through his career as such we can see interesting developments as will be illustrated. ${ }^{150}$

Governor Bell's attitudes toward the African land question were very similar to Sadler's in the sense that he wanted to keep a balance of power and peace and not to violate any African rights toward land nor disrupt social or institutional customs. He thought that this disruption would destabilize the region and cost the Colonial state a great deal of resources to keep the peace. If the state could avoid a quarrel it needed to try extremely hard to do so. It was in this spirit that Bell was given a more flexible set of guidelines than his predecessor and it was this flexibility that 
would lead to the growth of the cotton industry, that was heavily dependent on small holding African farmers. ${ }^{151}$

By this time the planter sector was still at a standstill and Bell recognized the lack of interest in Uganda. The soil was prime for planting and he knew this. He was interested in transforming Uganda into a crop producing colony, but his attitude was influenced by this lack of strong European demand for land. Bell's opinion on the expansion of European farming in Uganda was slanted toward the cautious side. He cautioned on the unsupervised expansion of planters and warned that a chaotic scramble for land would prove volatile to the African population and lead to discontent. Bell preached a careful and meticulous approach to the land acquisition question.

Bell wanted "Uganda to be for the Baganda." 152 Bell was adamant that the land be carefully surveyed and that it be divided demographically and estates distributed based on government issued criteria not personal. This would allow European sectors to be created and would facilitate the slow growth of European agricultural communities, that could be monitored and controlled by local administration. ${ }^{153}$ It was important to Bell's scheme that the available land was farmed adequately and that the limited resources should be utilized in areas of known potential. Instead of claiming land all over Uganda, Bell wanted to use land that was, without a doubt, totally usable farm land. As we look at this idea, Bell had a very valid point here. It would be very dangerous to let British planters decide where they wanted to farm because the land would have been divided haphazardly, one man might claim land and attempt to grow coffee and the soil come to be insufficient for that crop and only be suited for tea. This would lead the planter to either sell his land or move on. This makes perfect sense as Bell understood that Africans knew their land better than anyone else and knew what crops could grow well. 
Bell's scheme would also localize the demand for African labor, which would prevent competition in the sense that if the planters were spread around unorganized it might require Africans to travel a good distance to get to work whereas localized pockets of farming African works could be closer to these pockets and more apt to work. This would solidify the crowns roll in the proper distribution of labor for farms and would provide for a minimal effect on the cotton and cash crop industry, making it far easier for Europeans to farm. ${ }^{154}$

Bell noted that be two types of planters would emerge, the gentleman planter and the undesirables, these being Indians and corrupt British settlers. Bell was hoping that the gentleman planters would flock to Uganda, but was worried about the undesirables as they could upset the balance of peace. Bell was adamant though that Uganda was not a, "white man's country" and vowed that Uganda would not become a clone of South Africa nor the East Africa Protectorate. ${ }^{155}$ Bell even stated that Uganda was, “in every way unsuited for 'settlers,' if we mean by such a term men possessing more laboring capacity than capital. Persons of that class should be strongly dissuaded from trying their fortunes in Uganda." ${ }^{" 156}$ The CO endorsed Bell's ideas, to the point that circulatory literature was proclaiming that there was no room for unskilled labor nor would any man of an unrespectable quality nor one possessing insufficient capital be granted admittance in Uganda.

By 1908 the process for acquiring land was so difficult that it had an adverse effect on land applications. It was a difficult and lengthy process for anyone to go through in order to get land. This was made even more difficult by pressures for land alienation coupled with title and transfer confusion, mailo delineation, and inheritance fragmentation. These all played a great role in the hindrance of European settlement. The hoops were just too great and this hindered growth of the planter's sector and proved the land legislation highly inadequate. ${ }^{157}$ 
A committee was formed by a select group of administrators to grapple with this problem and to evaluate the various regulations, so as to reach an agreement on a single piece of legislation that would cure the ailments of Uganda. This committee recommended the Australian Torrens model with several modifications by which hoped to solve the problems at hand, those being land registration, transferal, and sales. Thus the Land Law of 1908 and Buganda Law of 1909 were born and both submitted to the colonial government for review.

These laws were an attempt to quench the problems of land acquirement, to redefine the parameters of the peasants and planters. The Buganda Agreement could not legally be altered without a special order from the Colonial government, but they could reinterpret the agreement to create a more attractive system. The committee decided that land was to be allodial, or owned without any superior land lord. The committee also wanted to set forth guidelines that planned out the proper ways to alienate African land to non-Africans. This created trouble for Africans, so much so that the Lukiiko asked for a clarification of their rights to land.

The mailo was also redefined and categorized two ways, the Butaka, or personal property that could be sold and inherited, and Butangole which was a permanent fixture to a holder's land that could not be sold, only transferred. It was this interpretation that made it easy to alienate African land which met stiff opposition. Even with these land explanations, the CO still preferred the leasehold land, as opposed to freehold land, simply because they did not want to lose land. It still wanted its property and to delineate the prices of land, and to collect the revenue, which lead the $\mathrm{CO}$ to seek alternative policies regarding leasehold land because they knew that with the flexibility of new land applications, there would be an influx of European interest in Uganda Through the price of land going up, it would provide and guarantee revenue through rent. If the 
crown owned the land it would make money through rent and the mailo could now be alienated with the mutual consent of the Lukiiko and the governor without ever involving the CO. ${ }^{158}$

What is interesting here is that even though the colonial government had been debating this land issue, by 1910 there were only 16 plantations encompassing an average 113 acres of cultivated land. Bell treated this sector as a supplement to African farm production. This would remain his stance until his departure from office in 1910. Bell was able to shed some light on the African disadvantage and attempted to give Africans a fair shake. Nevertheless his departure saw a change in local administration and their views on settlement which led to an even stronger increase of European planters in $1911 . .^{159}$

1911 was an important year for Uganda, as it marked the arrival of Sir Frederick Jackson as governor and an increase of land applications from Europeans. 1911 saw the growth and importance of the cotton industry in Uganda, which were explicitly discussed in Governor Jackson's reports. ${ }^{160}$ In Jackson's 1911-1912 report, he states that ginned cotton, and cotton seeds were the primary exports from Uganda and that they increased from the year previous. His report also illustrates the estimates between the ratios of Africans and non-Africans. According to this report 11 European children were born in Uganda in 1911 and only four people were married. This shows us that there wasn't a significant number of Europeans in this Africa colony in 1911. ${ }^{161}$

Jackson's first annual report as governor also talks about the number of land grants in Uganda for the 1911-12 year. Only 90 were applied for and out of those 65 were leases. Out of those 65, 23 were for agricultural land and the other 40 were for townships. Out of the 7,698 acres available, 6,062 acres were African lands transferred to the crown. According to Jackson, African land, as set forth by the land laws, in Buganda primarily, was transferred by the African landholder 
as crown land, and only after the consent of the "native council." The colonial state would then set the price and sell it to a non-African and compensating the original owner for their property. The purchaser would then be allotted the same rights to timber and minerals as the original owner. ${ }^{162}$

The problem with this, and Jackson alludes to this, is that the only workable land left in Buganda was owned by the Baganda which required the process mentioned above to shift the lands from the hands of the Africans, to the hands of the British planters. Buganda was clearly the favorite spot for planters. Its location close to Lake Victoria and its fertile soil made it optimal real estate. Jackson could foresee a population boom and noted in his report that Uganda was well on its way to becoming a planter's colony. With the exports of cotton and more and more African land being transferred over to the state, the economy would be booming by the end of the year.

With regards to cotton, Governor Jackson's report on agriculture is almost exclusively about the cotton industry. By 1911 cotton was becoming a staple crop, especially cotton of the American variety. Jackson said that the largest increase of farming area was land that was sanctioned for cotton growing, primarily in the Eastern Province. Jackson noted by the end of the year new more robust cotton would be cultivated and that it would be most satisfactory ${ }^{163}$.

According to Jackson's report second to cotton production was coffee. It was the main item produced on non-African farms with rubber being a close second. This is very interesting because he was quick to assert that the coffee was grown on European farms and the cotton was grown on African farms. This is important because it shows, through Jackson's eyes, that the big producers for Uganda were the cotton farmers and these farms would make the Baganda very rich. ${ }^{164}$

Though Jackson saw that Africans had an opportunity to be successful cotton farmers, he was worried about the shortage of labor in Buganda, though he assured the $\mathrm{CO}$ that the 
improvement in transportation would alleviate the problems as workers could be transported to and from their place of employment. With the creation of plantations came the need for labor and the more plantations in existence, the more laborers one needed. Jackson had high hopes for Uganda, as he said in his concluding remarks of the report, the big problem facing Uganda was the ability to transport goods efficiently utilizing the Uganda railway in order to sell them on the market. ${ }^{165}$ Jackson's report tells us that by 1911 and after Uganda was in a state of rapid expansion in regards to the planter sector.

The growth of the planter sector was so great, that by 1912-13 the demand for freehold land was so high that there wasn't enough land for distribution and prices were going up because African land holders were selling out. The Colonial state had relaxed its policy on the freehold alienation of crown land in an attempt to promote even further growth. They were simply taking advantage of the situation. ${ }^{166}$ Governor Jackson would not let such ideas be entertained given his good record in regards to the rights of Africans, especially with his defense of the Maasai in Kenya. Jackson was well aware of the situation and understood that if an African wanted to sell his property for just compensation, then it was up to him to do so. At best, Africans could be persuaded to sell their land not be forced into it. This is a key factor in the type of leader Jackson was. As we have discussed in his previous experiences, Jackson was always sympathetic toward African rights and he understood very well what Sadler and Bell were trying to accomplish, though he also knew in order to promote a healthy colony, the land would have to be designated in an organized gentlemanly fashion. All could benefit with the proper organization which would lead to economic prosperity in Uganda.

Uganda continued to slowly evolve and by 1913-14 the demand for land in Uganda had reached magnificent proportions, the classic example of a boom. In Governor Jackson's fiscal year 
report 1913-14, over 137 applications for crown and mailo land were noted and out of the 88 applications for crown land, 53 were approved, each approval averaging 936 acres per grant. Out of the 49 mailo applications only six were denied, the other approvals being held as small supplementary lots to larger crown land operations. ${ }^{167}$ With the land laws becoming flexible, it thus was becoming easier for planters to acquire land, though this boom in the planter section made the Colonial state take notice and question whether or not African rights were being protected, this being assured by Deputy Governor Tompkins. This was a big problem because Tompkins stated that African rights were being protected, but the Baganda thought differently due to an article published in the Uganda Herald outlining the easiest way to acquire mailo land without the influence of the crown. ${ }^{168}$ Tompkins neglected to investigate this story and accounts of fraud against African landholders, which led to the hiring of Major W. A. Burn to investigate the case of the Baganda and take their grievance before the Secretary of State. This created a rift between Africans and Europeans and also illustrates the reactive policies the British employed when it came to the planter sector. Those in opposition to this claim were Tompkins as well as the members of the committee that enacted the Native Land Ordinance and the Crown Land Ordinance. ${ }^{169}$

While Tompkins supported the European, Jackson as well as the director of Agriculture Samuel Simpson, supported the Baganda. These men knew what was right and they understood that the greed that fueled many planters would eventually take over if regulations were not put in place to keep proprietors at bay. A petition was made and the case for the Baganda was opened and discussed, and since the Baganda were instrumental in the creation of the Buganda Agreement, it was ruled in their favor that any excess land gain by the Baganda would stay with the Baganda and not be taken by the Colonial state for its own whims. All the Baganda wanted was to run their 
farms in peace and without headaches caused by asinine colonial rules and interpretations which Jackson severely criticized saying,

I am of the opinion that they have misinterpreted both the spirit and the actual meaning of clause 15 of the Agreement in regard to the right of the administration to deal with shortages and excesses... I consider that apart from this undoubted feeling amongst the people... that the administration is attempting to deprive them of the implied, if not actual, legal right to settle the allotment of the 8,000 square miles amongst themselves... It appears to me to be scarcely dignified and keeping with the traditions of the government of a Native Protectorate to quibble over such a matter" 170

The ruling was in favor of the Baganda and their claims were to be honored by the Colonial state and were largely considered inviolate. Land could be alienated to non-Africans with the exception of any excess land in Buganda. This shows us that the underlying issues in Uganda were merely reacted upon and no real long term solution was be devised. When these problems would arise the colonial government would simply react to it, pass an ordinance to silence the masses until their next grievance arose.

Despite the turmoil, 1913-1914 was a good year for Uganda when it came to production. Governor Jackson stated in his annual report that the demand for agricultural land outside Buganda was increasing and that the most attractive areas were that of Masindi and Fort Portal. The Fort Portal area was slightly far from Lake Victoria, but still had good soil for planting. Also, the high price of coffee and high concentration of workers in Buganda, made it much more attractive to work in other sectors especially with less competition. ${ }^{171}$ According to Jackson the labor supply in Buganda was incredibly difficult because the demands of planters could not be met by the general population. There were more workers needed than those available. Jackson said that workers tended to work a few months, then move on to a different area and find work elsewhere. This created high turnover rates and sporadic employment. Jackson recognized 1914 as a slow year, but 
he said that things were looking up for the economy and that cotton and coffee we still the main crops in production. ${ }^{172}$

Analyzing this report, we can see that Jackson was concerned with the labor problem, but did not seem to be too concerned with anything else. He probably was more occupied with trying to figure out the labor and the Buganda issue discussed above. What is important about these reports and those from when he left office in 1917 is that the plantation sector in Uganda was growing and that cotton was becoming the staple crop, but the Colonial state still was grappling with how to proceed when it came to land acquisition.

By the time Jackson left his office as governor in 1917, an articulate political planters sector had emerged which put emphasis on individually capitalized estates based exclusively on the propagation of cash crops. By the end of Jackson's career as governor, the number of European plantations had risen to $193 .{ }^{173}$ Most new planters coming to Uganda had no prior experience in Uganda, which created a slightly disruptive dynamic that Jackson was concerned about.

With the Great War raging in Europe, one might think that it would have had an adverse effect on the plantation sector, but it didn't because the newly acquired farms had yet to fully develop. It takes five years for rubber trees to develop and even longer for coffee to properly grow. Cotton was still the most attractive crop to grow. Though planters were in demand for labor they never ran out, even during the war years. The way they were able to accomplish this was by drawing labor from peripheral areas and drawing them in to work. This was the plan that the planters used to prevent labor, shortages. Soon enough most colonial administrators were consumed with the idea of plentiful labor including Simpson. Jackson's administration would see an influx in administrative assistance towards planters in the shipping and market sectors. ${ }^{174}$ The 
colonial government also granted assistance to planters through loans to help them with exportation. By the end of Jackson's governorship his administration felt that the plantation sector was healthy and functioning properly, well on its way to becoming great.

Despite this he left office with three problems at hand. Though the planter sector was growing, it had no long-term goals for the future. Also, a main source of contention still left behind, was the fact that Baganda land was being taken. They were not angry with the fact their land was eligible for selling, but they were angry over who facilitated the selling of their property. They wanted to be in charge of that and not the Colonial state. Lastly Buganda was still in the center of popularity when it came to attractive land and the Baganda chiefs were still showing opposition to political and financial opportunities.

Jackson grappled with these issues until he left office and found himself in an interesting position. Jackson was concerned with African rights to land, but he was also supportive of European settlement. This was clearly illustrated in 1915 when he approved Sir W. M. Carter's views on African land and recommended them to the Secretary of State, Bonar Law. Carter's letter contained evidence from three past surveys he had conducted, all dealing with the African land issue that he believed were the best ideas to promote a stronger Uganda utilizing European plantations. The first of the three surveys was conducted in 1906 and dealt with Buganda, it determined that freehold land tenure was best for Buganda and declared all unsettled land to be British land. ${ }^{175}$ The second survey determined that a great deal of land in Buganda was primarily owned by chiefs and that in order to protect African land rights, peasants would have to become rent paying occupants of a chief's estate. According to Carter this would release land for European occupation. ${ }^{176}$ Thirdly, the last survey conducted determined that it was dangerous for Britain to allow the creation of a landless class. It was important for Africans to be contributing members of 
society and if a landless class could be avoided, it would hinder the promotion of social unrest. ${ }^{177}$ The Secretary of State was not in favor and in January of 1916 he replied to Carter and said that the interests of development and peasants were not considered in this argument, in order for Uganda to function and thrive all land would have to be under the tenancy of British government. ${ }^{178}$

In analyzing Jackson's approval of Carter's letter to Bonar Law we can see Jackson as a fair man. Jackson knew that African cotton was clearly the facet in which Britain was going to gain the most from Uganda. He also knew that European settlement could indeed help Uganda's economy, if done correctly. Carter did a great deal of work conducting the surveys, as well as compiling the reports. Jackson wasn't going to simply brush Carter's work under the table. He had experience with surveying in his early career and he knew the difficulty figuring out land issues when he dealt with the Uganda Railway and the Maasai in Kenya. This is why Jackson approved of Carter's letter to Bonar Law. Plus there was a chance that the Secretary of State would approve of the letter and therefore help pave the way for more European settlement in Uganda, though this would ultimately fail. Jackson was a fair gentleman and cared about others ideas. He was simply giving Carter a chance to do something in the furtherance of European settlement and the creation of European plantations.

Even though Carter's letter was largely a failure, African farms continued to prosper and were clearly doing well, so well that African cotton production would soon overshadow European plantations. Especially after WWI we see the collapse of the European plantation sector and the rise of the African cotton grower largely because the price for coffee and rubber dropped and Europeans were being paid lessm, where African cotton was being exported to India and they were 
getting the full price for cotton. This led to the disruption of the European plantation sector because African cotton was by far, the best product coming from Uganda.

Jackson knew that cotton was going to take over Uganda, he just didn't know when. As coffee, rubber, and other cash crops were plateauing, cotton was slowly pulling ahead. Jackson was a fair man and he knew that Europeans and Africans could live harmoniously in Uganda if the proper steps were taken to ensure this, primarily with the land issue. What Jackson was thinking when it came to Carter's favor of European settlement was that if large European plantations were built, Africans could work those fields and make a living and the European interests could make money as well. Both sectors could thrive if the proper measures were taken, but this was not the case. African cotton would be the staple export of Uganda and we see this after 1920. Uganda did indeed turn out to be an African farming mecca.

When Sir Frederick Jackson left Kenya in 1911 and came to Uganda, a very complex history had preceded him. Jackson inherited a Uganda that was still in its infancy, though under his governorship was able to aid in the development of the Uganda economy. This economy was transformed from a small, nonexistent tribal economy to a planter economy that was based upon the growing of cash crops as means of capital, primarily cotton and coffee. Though Jackson was integral in the creation of the Buganda Agreement of 1900, his service in Kenya took him away from Uganda, but when he returned, the Uganda he came back to was a very different land, deeply rooted in the production of cash crops where Europeans were competing with Africans for precious fertile soil. Again, like his time in Kenya, Europeans were after land that belonged to Africans, similar to the Maasai dilemma he faced in Kenya. Jackson was able to lead Uganda towards a better future and on his retirement Uganda was well on its way towards the development of an economy centered on the mass production of cotton. 


\section{Chapter 5}

\section{Conclusion}

This journey began in the 1890's and concluded in 1917 with a great many topics covered ranging from early European settlement to deep rooted questions of the colonial period. This thesis attempted to illustrate the career of Sir Frederick Jackson and the events that took place within his career as a British explorer and later administrator. Jackson is important to British history in East Africa for several reasons; one being his involvement in the early formative period of the British protectorates in Africa. Though Jackson's career wasn't as sensational as the likes of Dr. Livingstone and H. M. Stanley, we can see that Jackson was faced with a great many problems ranging from armed conflicts to administrative tasks, such as settling and resettling the Maasai or deciding how to cope with the growing plantation sector in Uganda.

Jackson was a gentleman. He was a man of principle and integrity who always sought to do what was right. He exhibited the qualities all good gentleman should possess. He was honorable, trustworthy (being one of many requirements of Freemasons as shown in chapter two) and cared greatly about others. He was spry, kind, and smart, but most of all adventurous. Jackson was able to come to Africa as a young man and gain vast amounts of experience from his early hunting trips with $\mathrm{H}$. Rider Haggard. He was able to gain knowledge of the flora and fauna, as well as the unique people that were very different than the typical Briton back home. Jackson wanted to explore the land initially simply because it was exotic. Africa promised a great deal of adventure. With the interior opening up and all the land to be had, Jackson, among many others, heard the call. Jackson was ambitious and ready for adventure. He knew that his passion for hunting would be well entertained in Africa, and initially that was the only reason he came to 
Africa. Jackson had no real interest in becoming an administrator in East Africa. All he was interested in doing was discovering birds, plants, and hunting big game.

Jackson would soon realize that his hunting trips would bring him into contact with Africans and many different kinds of people from many different walks of life and backgrounds. This would all add to Jackson's experience in Africa, and eventually lead to Jackson's career as an administrator in East Africa.

What has been shown is that Jackson was indeed an agent of empire. He never sought to promote the development of the EAP, he was concerned with African affairs and rights and when it came to a good adventure he was always ready as was illustrated with the Emin Pasha expedition, the Karl Peters dilemma, and the Buganda issue. Though Jackson was merely on these adventures in a humanitarian sense, he inadvertently helped solidify British rule in East Africa by signing treaties with local chiefs and making enemies with foreign dignitaries (Peters) in the name of Britain. Jackson was integral in the promotion of British rule in East Africa because of his success as an explorer. We can see that Jackson eventually went on to be the Lieutenant Governor of Kenya and then Governor of Uganda, so in this instance he was definitely working for British interests. He did help usher in an era of European domination, even though he never meant to. Jackson had no expectations in being involved with the Empire let alone becoming a Governor of a colony. Jackson was in Africa simply for sport.

This is significant because this shows that though Jackson was in Africa for sport, he inadvertently became an agent of Empire and that Britain was able to conquer East Africa not only by deliberately sending people to Africa to acquire land, but by capitalizing on the adventurous nature of a select few and using their, "holiday" time as a way of opening up the interior for 
settlement. This was Jackson's case. Jackson's career as an explorer and in the IBEA was important because the interior was opened up to European conquest. Without explorers like Jackson the interior would have been vastly undiscovered and perhaps the development of Britain would have been vastly different without the interests in Africa. Jackson with the help of his guides were able to blaze the trail through the ten mile stretch of land at the coast and discover the people, customs, and land surrounding Lake Victoria and give Britain a reason to promote colonization. And to scramble for those interests in Africa.

The scramble for Africa began in the 1880's and when Jackson came it Africa it had largely been divided. An example of Jackson's involvement in the scramble was his exchanges with Karl Peters, who claimed to represent Germany. With Peters' reading of Jackson's mail and rushing to Buganda to sign a treaty for Germany, it can be shown that Jackson followed Peters to Buganda and afterward gained a treaty for the IBEA, thus helping solidify British influence in Buganda. This shows that by the time Jackson went in search of Emin Pasha he had gained some prestige, and it was at this point that Jackson developed into the administrator.

With the valuable experience Jackson gained from these diplomatic escapades, his attitude toward the African population not only developed, but it solidified and never changed. Jackson was always in favor of Africans and always treated them with respect largely in part because they treated him well especially the Maasai who he dearly respected, so much so that he fought for the in Kenya during the relocation. He had a less than favorable opinion of Indians, to the point where he mentions that he is, "repulsed" by many. This could be a stereotypical example of the colonial attitude towards Indians viewing them as lesser beings. Possibly because India was the jewel of the British Empire and it was India that provided Britain with many precious items such as tea and 
spices. Indians were usually servants so in this case Jackson suffered from that mindset, but he always cared for Africans and fought for them.

Thus Jackson was sympathetic to African rights throughout his entire career. We can see him employing a healthy number of Africans in his early explorations and always wanting to make sure they were kept well and given proper provisions. These guides, as shown in chapter two, were important because they helped Jackson survive. Guides spoke the local language, they knew the land, they knew animal patterns and they were helpful in mapping the surroundings. Without guides Jackson would never have ventured into the interior. Good help was hard to find and with few British men around willing to trek through the wilds of Africa, Jackson relied heavily on African assistance. It was this assistance that kept him safe and brought him back in one piece. This experience was the direct cause of Jackson's attitudes toward Africans, which is why he was concerned with their safety during the construction of the Uganda railway, why he fought for Maasai rights, and especially his discontent with European planters in Uganda. Jackson knew that Britain was turning a hungry eye on Africa and he knew that African rights would be at risk if someone didn't fight for them. He knew that if African interests were not defended that Africans would lose their liberties and face difficulties. Jackson defended Africans during the building of the Uganda Railway knowing well that this would usher in European settlement faster than any other means. Trains are faster than wagons. Jackson knew this, but in order to keep the status quo he went along with the construction, similar to his actions in relation to the Maasai move. Jackson fought for the Maasai and yet they were still displaced. Strangely Jackson was conveniently given his governorship of Uganda in the middle of the Maasai crisis as a way of removing his opposition to the Maasai reservations to make it easier for Britain to deal with the Maasai to better suit their 
agenda. This was one of the most important events in Jackson's career because it was this promotion that landed him a governorship.

There are several key events in this thesis, those being; Jackson's early explorations, the Emin Pasha expedition, and the construction of the Uganda railway, the Maasai move, and the most complicated of all the peasants vs. planters debate in Uganda. Jackson's early explorations helped him gain a foothold in East Africa with the IBEA and helped him gain experience through contact with the African population and the land. His time with the IBEA also saw the signing of a treaty with Buganda and thus solidifying British rule in that area. Jackson was involved with this and therefore can be said to have contributed with widening the British sphere of influence in East Africa. With Jackson taking charge, one can see the development of the Uganda railway which put Jackson in his first real administrative position and confirms how important the railway was to the ushering in of European settlement. With Jackson having a hand in the creation of the railway, he gained further experience in dealing with the European settler question. The settlement question would plague Jackson for the rest of his career as he constantly had to grapple with the idea of Europeans wanting African land, the classic example being the Maasai Move.

The Maasai move was a key factor in Jackson's tenure in Kenya because European settlers wanted the best land and this land was largely inhabited by the Maasai. Jackson recognized this and took a firm stance for African rights. He believed that the Maasai should have been given ample land and that their rights not infringed upon in regards to cattle. Jackson opposed the first reservation because he claimed it wasn't large enough and that Maasai land was being infringed upon by European interests. The Maasai were moved several times and Jackson was always alert to make sure they were taken care of, often opposing the higher administration. This not only aided 
Jackson in understanding the competition between African and European land interests, it would also give him the experience needed to deal with the planter problems in Uganda.

The planter's debate in Uganda began in 1900 with the signing of the Buganda Agreement, in which Jackson played a role. What one can see with that discussion is one of the most important topics discussed in this thesis. The planter vs peasants debate was extremely important to the development of Ugandan history, but it is riddled with gaps in the historic record. Very little information exists on this topic with the exception a few good journal articles, such as Taylor and Youé, and a paragraph or two in a survey work on African history such as the Oxford History of East Africa Volume II. Jackson's tenure in Uganda at this time is sparse as well, which explains the heavy reliance on the Uganda annual reports prepared by Jackson.

What we can see through what has been collected from these reports is that by the time Jackson came to Uganda he had been through ten years of treaties and discussion after discussion as to who had the right to land. Who did the land belong to and how could land be bought and sold? Not to mention what crops were to be farmed and by whom, cotton being the primary crop reserved for small African farms. By the time Jackson came to Uganda it had slowly developed into a planter society with coffee and rubber being the primary goods produced. Jackson's governorship saw prosperity in Uganda and a slow growth rate that would eventually turn into a boom after the Great War and into the 1920's. Jackson's governorship was not a proverbial, “bed of roses" as there were some difficult issues that were never taken care of but merely, "papered over" to appease varied administrators.

In the end one is left with a very colorful career and a great deal of success for Sir Frederick Jackson. The events that he dealt with not only gave him knowledge, but strength to deal with 
taking up the sword and gavel for the crown. Jackson was a good man who loved the outdoors and helping people. He was a successful administrator and is a classic example of an agent of empire. This thesis was written to explain the importance of several of the events of Sir Frederick Jackson's life, but also grapple with some of the issues that plagued colonial East Africa His expeditions, the Uganda Railway, the Maasai move and the planters' argument were all meant to help illustrate the times in which Jackson worked. What one can conclude from this thesis is thus: Sir Frederick Jackson, though not as flashy and sensationalized as some adventurers, was an important factor in the formation of British rule in East Africa and the historical events within the context of his career from the 1890s to his retirement in 1917 were integral to the promotion of colonial rule and European settlement in East Africa. 


\section{Appendix 1}

Jackson, Sir Frederick John (1860-1924). Early colonial administrator, big-game hunter, and ornithologist. Born in Yorkshire and educated as Jesus College, Cambridge. After arriving in east Africa in 1884, Jackson lived in Lamu, explored the region, and hunted big game in places such as the Kilimanjaro region. On 3 October 1888, he joined the Imperial British East Africa Company (IBEAC). During 1889-1890, Jackson led an IBEAC expedition, which, after a detour to Mt. Elgon, eventually took him to Buganda in pursuit of the German imperialist Karl Peters. On 24 September 1890, Jackson received an appointment as consular agent for Lamu. In November 1891, he agreed to serve as transport officer in an expedition led by Captain J. R. L. MacDonald to survey a route for the Uganda Railway. In 1892, illness forced him to return to Great Britain, but he took advantage of his African experience to gain an appointment with the new British administration in Uganda in July 1894. Jackson remains in Uganda service until the transfer of that protectorate's Eastern Province to the East Africa Protectorate (EAP) in 1902, when he shifted to Nairobi to take the new post of deputy commissioner, later lieutenant governor. In 1905 and again in 1909, Jackson took over the EAP administration pending the arrival of new governors.

Jackson was generally not popular with superiors such as Sir Charles Eliot and Sir Percy Girouard because he did not share their enthusiasm for promoting European settlement. Indeed, Jackson played a considerable part in the events that led to Eliot's resignation. Girouard pushed hard for Jackson's transfer from the EAP. In April 1911, he left Kenya to take up the post of governor of Uganda, which he held until his retirement in 1917. He died on 3 February 1924. His memoirs, Early Days in East Africa, were published posthumously in 1930.

\section{End Notes}

\footnotetext{
${ }^{1}$ Sir Frederick Jackson, Early Days in East Africa. (London: Arnold, 1930), 4.

${ }^{2}$ Ibid.

${ }^{3}$ Ibid.,3.

${ }^{4}$ Ibid.

${ }^{5}$ Ibid.,4.

${ }^{6}$ Ibid.

${ }^{7}$ Ibid.

${ }^{8}$ Ibid.,5.

${ }^{9}$ Ibid.,7.

${ }^{10}$ Ibid.,9.

${ }^{11}$ Ibid.

${ }^{12}$ Ibid.

${ }^{13}$ Dane Kennedy, The Last Blank Spaces: Exploring Africa and Australia. Cambridge, Mass.: Harvard University Press, 2013164.

${ }^{14}$ Ibid., 164.

${ }^{15}$ Ibid.
} 
${ }^{16}$ Ibid., 165.

${ }^{17}$ Ibid.

${ }^{18}$ Ibid., 164.

${ }^{19} \mathrm{Ibid}$.

${ }^{20}$ Ibid., 165.

${ }^{21}$ Ibid., 171.

${ }^{22}$ Ibid., 170.

${ }^{23}$ Ibid., 171.

${ }^{24}$ Ibid., 178.

${ }^{25}$ Ibid., 190.

${ }^{26}$ Jackson, Early Days 13.

${ }^{27}$ Ibid.

${ }^{28}$ Ibid., 27.

${ }^{29}$ Ibid., 28.

${ }^{30}$ Ibid.

${ }^{31}$ Ibid.,29.

${ }^{32}$ Ibid., 30.

${ }^{33}$ Ibid.

${ }^{34}$ Ibid.,31.

${ }^{35}$ Ibid.,36.

${ }^{36}$ Ibid.,40.

${ }^{37}$ Ibid.

${ }^{38}$ Ibid.

39W.O. Henderson, "German East Africa 1884 to 1918" in History of East Africa, Volume 2, ed. Vincent Harlow et al. (Oxford: Clarendon Press, 1976), 124.

${ }^{40}$ Jackson, Early Days, 63.

${ }^{41}$ Ibid.,64.

${ }^{42}$ Ibid.,69.

${ }^{43}$ Ibid.

${ }^{44}$ Ibid.,101-102.

${ }^{45}$ Ibid.,106.

${ }^{46}$ Ibid.,107.

${ }^{47}$ Ibid.,131.

${ }^{48}$ Ibid.

${ }^{49}$ Ibid.,132.

${ }^{50}$ D.A.Low, Fabrication of Empire.Cambridge: Cambridge University Press,2009 75.

${ }^{51}$ John Galbraith, Mackinnon and East Africa 1878-1895; a Study in the 'New Imperialism.' (Cambridge: Cambridge University Press, 1972),153.

${ }^{52}$ Kenneth Ingham, The Making of Modern Uganda. (London: Allen \& Unwin, 1958), 42.

${ }^{53}$ Low, Fabrication, 94-5.

${ }^{54}$ Galbraith, MacKinnon, 154-55.

${ }^{55}$ Jackson, Early Days, 145.

${ }^{56}$ Ibid., 146.

${ }^{57}$ Galbraith, MacKinnon, 151.

${ }^{58}$ Ibid.

${ }^{59}$ Ibid.,154.

${ }^{60}$ Jackson, Early Days, 154.

${ }^{61}$ Ibid.,156.

${ }^{62}$ Ibid.,160.

${ }^{63}$ Ibid., 165.

${ }^{64}$ Ibid., 180.

65 Marie De Kieweit Hemphill, "The British Sphere 1884-94" in History of East Africa, ed. Roland Oliver et al. (Oxford: Clarendon Press,1963),413.

${ }^{66}$ Ingham, Making, 42.

${ }^{67}$ Low, Fabrication, 75.

${ }^{68}$ Ingham, Making, 42. 
69 Ibid.

${ }^{70}$ Low, Fabrication, 75.

${ }^{71}$ Jackson, Early Days, 151.

72 Ibid.,253.

73 Ibid., 260.

${ }^{74}$ Ibid.

${ }^{75}$ Low, Fabrication 76.

76 Jackson, Early Days, 263.

77 Ibid.

${ }^{78}$ Ibid.

${ }^{79}$ Ibid.,265.

${ }^{80}$ Ibid.

${ }^{81}$ M.P.K. Sorrenson, Origins of European Settlement in Kenya (London: Oxford University Press, 1968$), 17$.

82 Ibid., 19.

83 Ibid., 20.

${ }^{84}$ Ibid., 21.

${ }^{85}$ Jackson, Early Days, 321.

${ }^{86}$ Ibid.

${ }^{87}$ G. H. Mungeam, British Rule in Kenya: 1895-1912; the Establishment of Administration in the East Africa Protectorate (Oxford: Clarendon P., 1966.), 36.

${ }^{88}$ Ibid., 38.

${ }^{89}$ Sorrenson, Origins, 22.

${ }^{90}$ Jackson, Early Days, 326.

${ }^{91}$ Ibid.

92 Ibid., 327.

${ }^{93}$ Sorrenson, Origins, 23.

94 Jackson, Early Days, 319.

${ }^{95}$ Ibid.

${ }^{96}$ Ibid.

${ }^{97}$ Ibid., 333.

98 George Bennett, "Settlers and Politics in Kenya" in History of East Africa, Volume 2, ed. Vincent Harlow et al. (Oxford: Clarendon Press, 1976), 282-83.

${ }^{99}$ Dispatch from Jackson to Sec. of State, March 17 1907, BNA: CO533/28.

100 Ibid.

101 Ibid.

102 Ibid.

${ }^{103}$ Ibid.

104 Ibid.

105 Ibid.

106 Ibid.

${ }^{107}$ Ibid.

${ }^{108}$ Norman Leys, Kenya. (London: Cass, 1973), 114.

${ }^{109}$ Sorrenson, Origins, 192.

${ }^{110}$ Ibid.

${ }^{111}$ Lotte Hughes, Moving the Maasai: A Colonial Misadventure. (Basingstoke: Palgrave Macmillan, 2006$), 28$.

112 Sorrenson, Origins, 192.

${ }^{113}$ W. M. Ross, Kenya From Within: a short political history. (London: Cass, 1968), 134.

${ }^{114}$ Ibid., 135.

115 Jackson, Early Days, 332.

${ }^{116}$ Ibid.

117 Ibid., 137.

${ }^{118}$ Leys, Kenya, 117.

119 Ibid., 118.

${ }^{120}$ Sorrenson, Origins, 195.

${ }^{121}$ Ross, Kenya from, 135.

122 Ibid., 136. 
${ }^{123}$ Hughes, Moving, 37.

${ }^{124}$ Abdullah Sara, Kenya at a Crossroads Administration and Economy Under Sir Percy Girouard, $1909-1912$ (New York London: Lexington Books Lanham Boulder 2015),45-46

${ }^{125}$ D.A.Low, "British East Africa: The Establishment of British Rule 1895-1912" in History of East Africa, Volume 2, ed. Vincent Harlow et al. (Oxford: Clarendon Press, 1976), 53.

${ }^{126}$ Mahmood Mamdani, Politics and Class Formation in Uganda (New York and London:Monthly Review Press, 1976) 43.

127 Thomas Taylor, "The Establishment of a European Plantation Sector within the Emerging Colonial Economy of Uganda, 1902-1919," The International Journal of African Studies, 19 No. 1(1886), 35.

${ }^{128}$ Christopher Youe, "Planters and Cotton Capitalists: The Dual Economy in Colonial Uganda," Canadian Journal of African Studies, 12, No.2 (1978) 164.

129 Taylor, "The Establishment," 36.

${ }^{130}$ Ibid.

131 Ibid.

${ }^{132}$ Mamdani ,Politics, 53.

133 Jan Jorgenson, Uganda a Modern History (New York: St. Martin's Press, 1981), 78-80.

${ }^{134}$ Cyril Ehrlich, "The Uganda Economy 1903-1945” in History of East Africa, Volume 2, ed. Vincent Harlow et al.(Oxford: Clarendon Press, 1976), 410-11.

135 Taylor, "The Establishment,"39.

136 Jorgenson, Uganda, 78.

137 Ibid.

138 James Barber, Imperial Frontier (Nairobi: East African Publishing House, 1968), 35-38.

${ }^{139}$ Ibid.

${ }^{140}$ Ibid., 40.

${ }^{141}$ Ibid.

142 Ibid., 41.

${ }^{143}$ D.A. Low,'Uganda: The Establishment of the Protectorate 1894- 1919," in History of East Africa, Volume 2 , ed. Vincent Harlow et al. (Oxford: Clarendon Press, 1976), 69-80.

144 Jorgenson, Uganda, 53-60.

145 Taylor, "The Establishment," 42.

146 Ibid.

147 Ibid.

148 Ibid., 43.

${ }^{149}$ Barber, Imperial, 42.

150 Ibid 43.

${ }^{151}$ Ibid.

152 Ibid.

153 Ibid.

154 Ibid 56.

${ }^{155}$ Kenneth Ingham, The Making of Modern Uganda, (London: George Allen \& Unwin Ltd,1958), 108.

156 Taylor, "The Establishment,"45.

${ }^{157}$ Ibid.

158 Ibid., 50.

${ }^{159}$ Ingham, The Making, 109.

${ }^{160}$ Great Britain, Annual Colonial Report for Uganda 1911-12, cmd. 6007-43, (London: HMSO,1913), 7.

161 Ibid.

162 Ibid.

163 Ibid., 20.

${ }^{164}$ Ibid., 21.

165 Ibid., 25.

166 Taylor, "The Establishment," 52.

167 Great Britain, Annual Colonial Report for Uganda 1913-14, cmd. 7622-22, (London: HMSO, 1915$), 10$.

168 Taylor, "The Establishment," 53.

169 Ibid.

${ }^{170}$ Ibid., 54.

${ }^{171}$ Great Britain, Annual Colonial Report for Uganda 1913-14, cmd. 7622-22, (London: HMSO, 1915$), 20$. 
${ }^{172}$ Ibid.

173 Taylor, "The Establishment," 55.

${ }^{174}$ Ibid., 56.

175W.E.F. Ward and L.W. White, East Africa a Century of Change 1870 to 1970 (New York: Africana Publishing Corporation, 1971) 145-147.

${ }^{176}$ Kenneth Ingham, A History of East Africa (New York: Frederick A. Praeger, 1962), 232.

${ }^{177}$ Ibid., 233.

178 Ibid.

${ }^{179}$ Ibid. 


\section{Bibliography}

\section{Primary Sources}

CO533/28, Original Correspondence, Kenya.

Jackson, Sir Frederick. Early Days in East Africa. London: Arnold, 1930.

Great Britain.Uganda Annual Report 1911-1912. London: HMSO, 1913.

Great Britain.Uganda Annual Report 1913-1914. London: HMSO, 1915.

Great Britain.Uganda Annual Report 1915-1916. London: HMSO, 1916.

\section{Secondary Sources}

Books

Barber, James P. Imperial Frontier; a Study of Relations between the British and the Pastoral Tribes of North East Uganda. Nairobi: East African Pub. House, 1968.

Galbraith, John S. Mackinnon and East Africa 1878-1895; a Study in the 'New Imperialism' Cambridge: University Press, 1972.

Harlow, Vincent T. History of East Africa, Volume 2. Oxford: Clarendon Press, 1976.

Hughes, Lotte. Moving the Maasai: A Colonial Misadventure. Basingstoke: Palgrave Macmillan, 2006.

Ingham, Kenneth. The Making of Modern Uganda. London: Allen \& Unwin, 1958.

A History of East Africa. New York: Frederick A. Praeger, 1962.

Jørgensen, Jan Jelmert. Uganda: A Modern History. New York: St. Martin's Press, 1981.

Kennedy, Dane. The Last Blank Spaces: Exploring Africa and Australia. Cambridge, Mass.: Harvard University Press, 2013.

Leys, Norman Maclean. Kenya. London: Cass, 1973.

Low, D.A. Fabrication of Empire. Cambridge: Cambridge University Press,2009.

Maxon, Robert M. and Thomas P. Ofcansky. Historical Dictionary of Kenya. New York: Rowman \& Littlefield, 2014.

Mamdani, Mahmood. Politics and Class Formation in Uganda. New York: Monthly Review Press, 1976.

Mungeam, Gordon Hudson. British Rule in Kenya: 1895-1912; the Establishment of Administration in the East Africa Protectorate. Oxford: Clarendon Press, 1966.

Oliver, Roland Anthony, Gervase Mathew, and Jean-Claude Nardin. History of East Africa. Oxford: Clarendon Press, 1963.

Ross, William McGregor. Kenya from Within: A Short Political History. London: Cass, 1968.

Sara, Abdullahi. Kenya at a Crossroads: Administration and Economy under Sir Percy Girouard, $1909-1912$.

Lanham, MD: Lexington Books, 2015.

Sorrenson, M. P. K. Origins of European Settlement in Kenya. Nairobi: Oxford University Press, 1968.

Ward, W. E. F., and L. W. White. East Africa; a Century of Change. London: Allen, 1971.

\section{Journal Articles}

Taylor, Thomas. "The Establishment of a European Plantation Sector within the Emerging Colonial Economy of Uganda, 1902-1919." The International Journal of African Historical Studies 19, no. 1 (1986): 35-58. 
Youé, Christopher P.,"Peasants, Planters and Cotton Capitalists: The "Dual Economy" in Colonial Uganda." Canadian Journal of African Studies / Revue Canadienne Des Études Africaines 12, no. 2 (1978): 163184. 